\title{
ॠUSGS
}

science for a changing world

Prepared in cooperation with the Illinois Environmental Protection Agency and the Federal Interagency Sedimentation Project

Estimating Suspended Sediment Using Acoustics in a Fine-Grained Riverine System on Kickapoo Creek at Bloomington, Illinois
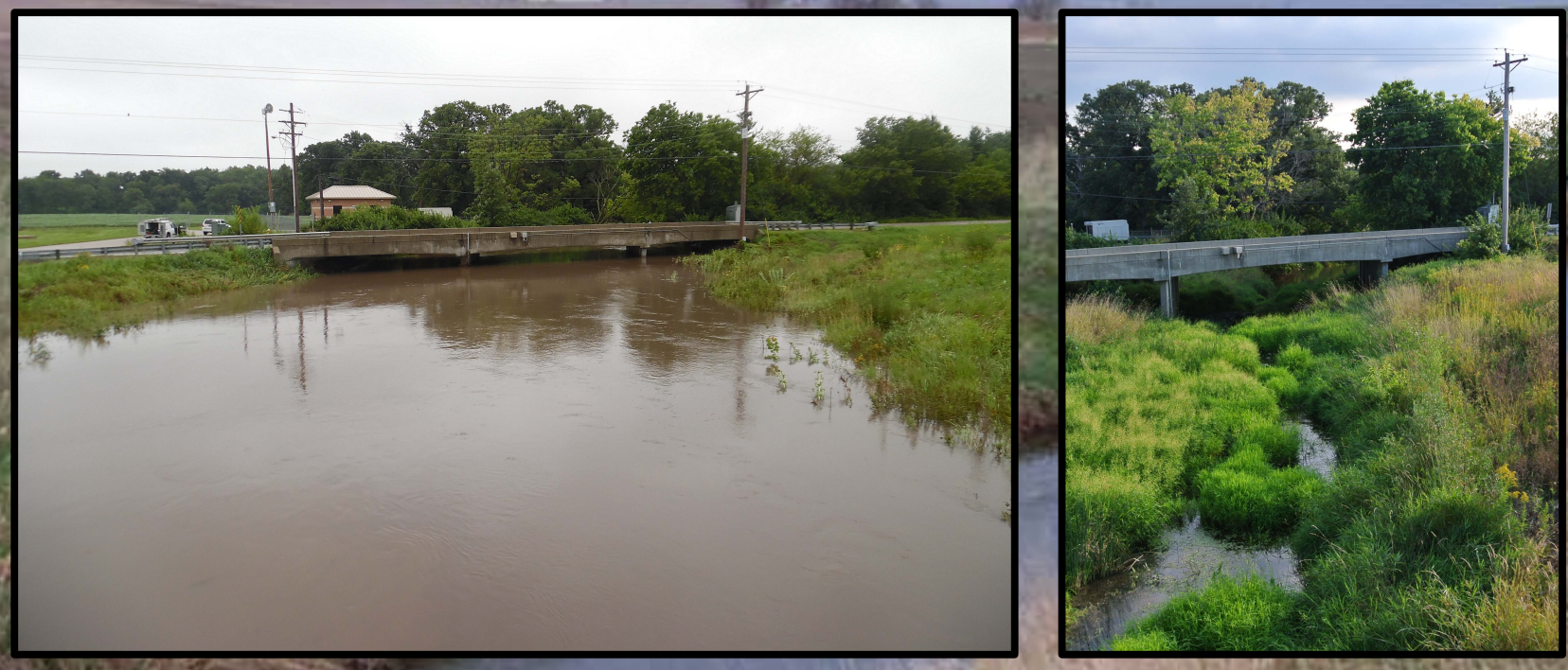

Open-File Report 2016-1117

U.S. Department of the Interior

U.S. Geological Survey 



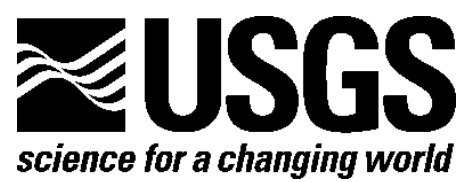

Prepared in cooperation with the Illinois Environmental Protection Agency and the Federal Interagency Sedimentation Project

\section{Estimating Suspended Sediment Using Acoustics in a Fine-Grained Riverine System, Kickapoo Creek at Bloomington, Illinois}

By Amanda D. Manaster, Marian M. Domanski, Timothy D. Straub, and Justin A. Boldt

Open-File Report 2016-1117

U.S. Department of the Interior

U.S. Geological Survey 


\section{U.S. Department of the Interior \\ SALLY JEWELL, Secretary}

\section{U.S. Geological Survey \\ Suzette M. Kimball, Director}

U.S. Geological Survey, Reston, Virginia: 2016

For more information on the USGS—-the Federal source for science about the Earth, its natural and living resources, natural hazards, and the environment-visit http://www.usgs.gov/ or call 1-888-ASK-USGS (1-888-275-8747).

For an overview of USGS information products, including maps, imagery, and publications, visit http://www.usgs.gov/pubprod/.

Any use of trade, firm, or product names is for descriptive purposes only and does not imply endorsement by the U.S. Government.

Although this information product, for the most part, is in the public domain, it also may contain copyrighted materials as noted in the text. Permission to reproduce copyrighted items must be secured from the copyright owner.

Suggested citation:

Manaster, A.D, Domanski, M.M., Straub, T.D., and Boldt, J.A., 2016, Estimating suspended sediment using acoustics in a fine-grained riverine system on Kickapoo Creek at Bloomington, Illinois: U.S. Geological Survey Open-File Report 2016-1117, 42 p., http://dx.doi.org/10.3133/ofr20161117.

ISSN 2331-1258 (online)] 


\section{Contents}

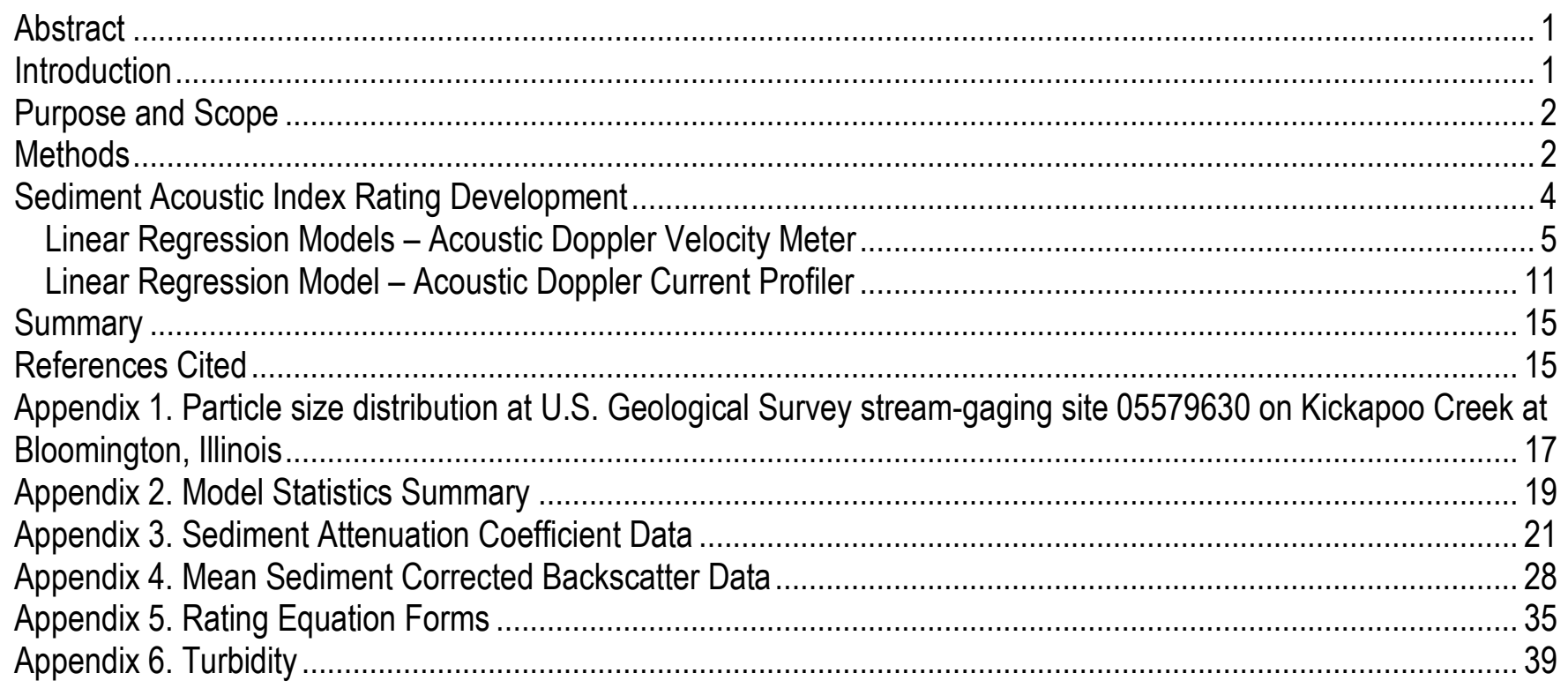

\section{Figures}

Figure 1. Map of the Kickapoo Creek drainage basin and location of U.S. Geological Survey streamgage 05579630 Kickapoo Creek at Bloomington, Illinois.

Figure 2. (A) Streamflow and suspended-sediment concentrations from samples and estimated using the sediment acoustic index method during a storm event on Kickapoo Creek at Bloomington, Illinois (U.S. Geological Survey streamgage 05579630). (B) Relation and hysteresis between streamflow and SSC samples. (C) and (D) Relation between sediment acoustic parameters and suspended-sediment concentration samples (from Landers and others, 2016).

Figure 3. (A) Scatter plots of all available data. Relation between suspended-sediment concentration and the sediment attenuation coefficient, and $(B)$ relation between suspended-sediment concentration and average sediment corrected backscatter.

Figure 4. (A) Linear regressions of suspended-sediment concentration versus sediment attenuation coefficient, and $(B)$ base-10 logarithmic transformed suspended-sediment concentration versus average sediment corrected backscatter in Kickapoo Creek, Illinois, 2009-15.

Figure 5. (A) Regression residuals of the predicted suspended-sediment concentration versus sediment attenuation coefficient, and $(B)$ predicted base-10 logarithmic transformed suspended-sediment concentration versus average sediment corrected backscatter in Kickapoo Creek, Illinois, 2009-15.

Figure 6. Predicted and observed suspended-sediment concentration from the best model for each configuration. The predicted concentration was found using acoustic parameter linear regression models. 
Figure 7. (A) Linear regressions of base-10 logarithmic transformed suspended-sediment concentration versus average sediment corrected backscatter for the ADCP and ADVM to show parallels between the two instruments. (B) Predicted and observed suspended-sediment concentration from the best model in 2011 for each instrument. 13 Figure 8. A plot of streamflow at the site in cubic feet per second, acoustic Doppler velocity meter (ADVM) and acoustic Doppler current profiler (ADCP) predicted suspended-sediment concentration, and actual suspendedsediment concentration values. The predicted values from the ADCP and the actual values lie within the ADVM ninety percent prediction interval.

Figure 6-1. Suspended-sediment concentration and turbidity linear regression models using turbidity data for (A) the YSI 6920 instrument, and (B) the SOLITAX instrument. 40

Figure 6-2. Predicted and observed suspended-sediment concentration using turbidity linear regression models presented in fig. 6-1.

\section{Tables}

Table 1. Acoustic Doppler velocity meter configurations during study period. 5

Table 2. Explanatory and response variable statistics for the best suspended-sediment concentration and acoustic parameter linear regression models.

Table 3. Suspended-sediment concentration and acoustic parameter linear regression models, coefficients of determination, and nonparametric smearing bias correction factor for the best model in each configuration. 10

Table 4. (A) Acoustic Doppler current meter configuration during study period. (B) Explanatory and response variable statistics for the best suspended-sediment concentration and acoustic parameter linear regression model. (C) Suspended-sediment concentration and acoustic parameter linear regression model, coefficient of determination, and non-parametric smearing bias correction factor for the best model in this configuration. Table 6-1. Data from the YSI 6920 and the SOLITAX that were used in the turbidity analysis. 


\section{Conversion Factors}

Inch/Pound to SI

\begin{tabular}{|c|c|c|}
\hline Multiply & By & To obtain \\
\hline \multicolumn{3}{|c|}{ Length } \\
\hline inch (in.) & 2.54 & centimeter $(\mathrm{cm})$ \\
\hline foot (ft) & 0.3048 & meter (m) \\
\hline mile (mi) & 1.609 & kilometer (km) \\
\hline \multicolumn{3}{|c|}{ Area } \\
\hline square mile $\left(\mathrm{mi}^{2}\right)$ & 2.590 & square kilometer $\left(\mathrm{km}^{2}\right)$ \\
\hline \multicolumn{3}{|c|}{ Volume } \\
\hline cubic foot $\left(\mathrm{ft}^{3}\right)$ & 0.02832 & cubic meter $\left(\mathrm{m}^{3}\right)$ \\
\hline \multicolumn{3}{|c|}{ Flow rate } \\
\hline cubic foot per second $\left(\mathrm{ft}^{3} / \mathrm{s}\right)$ & 0.02832 & cubic meter per second $\left(\mathrm{m}^{3} / \mathrm{s}\right)$ \\
\hline \multicolumn{3}{|c|}{ Mass } \\
\hline pound, avoirdupois (lb) & 0.4536 & kilogram (kg) \\
\hline ton per day (ton/d) & 0.9072 & metric ton per day \\
\hline \multicolumn{3}{|c|}{ Pressure } \\
\hline atmosphere, standard (atm) & 101.3 & kilopascal (kPa) \\
\hline \multicolumn{3}{|c|}{ Density } \\
\hline pound per cubic foot $\left(\mathrm{lb} / \mathrm{ft}^{3}\right)$ & 16.02 & $\begin{array}{l}\text { kilogram per cubic meter } \\
\left(\mathrm{kg} / \mathrm{m}^{3}\right)\end{array}$ \\
\hline
\end{tabular}

Temperature in degrees Celsius $\left({ }^{\circ} \mathrm{C}\right)$ may be converted to degrees Fahrenheit $\left({ }^{\circ} \mathrm{F}\right)$ as ${ }^{\circ} \mathrm{F}=\left(1.8 \times{ }^{\circ} \mathrm{C}\right)+32$.

Temperature in degrees Fahrenheit $\left({ }^{\circ} \mathrm{F}\right)$ may be converted to degrees Celsius $\left({ }^{\circ} \mathrm{C}\right)$ as ${ }^{\circ} \mathrm{C}=\left({ }^{\circ} \mathrm{F}-32\right) / 1.8$. 


\section{Abbreviations}

$\begin{array}{ll}\text { ADCP } & \text { acoustic Doppler current profiler } \\ \text { ADVM } & \text { acoustic Doppler velocity meter } \\ \text { Amp } & \text { backscatter amplitude } \\ \text { ANCOVA } & \text { analysis of covariance } \\ \text { BCF } & \text { bias correction factor } \\ \text { EWI } & \text { equal width increment } \\ \text { kHz } & \text { kilohertz } \\ \text { MeanSCB } & \text { average sediment corrected backscatter } \\ \text { OLS } & \text { ordinary least squares } \\ R^{2} & \text { coefficient of determination } \\ \text { SAC } & \text { sediment attenuation coefficient } \\ \text { SAID } & \text { surrogate analysis and index developer } \\ \text { SSC } & \text { suspended-sediment concentration } \\ \text { TRDI } & \text { Teledyne RD Instruments }\end{array}$

\section{Acknowledgments}

The monitoring effort included a U.S. Environmental Protection Agency (EPA) National Nonpoint Source Pollution (NPS) monitoring project using funds under Section 319 of the Clean Water Act, which were distributed through the Illinois Environmental Protection Agency. Additional monitoring funds were provided by the U.S. Geological Survey and the Federal Interagency Sedimentation Project. 


\title{
Estimating Suspended Sediment Using Acoustics in a Fine-Grained Riverine System on Kickapoo Creek at Bloomington, Illinois
}

\author{
By Amanda D. Manaster, Marian M. Domanski, Timothy D. Straub, and Justin A. Boldt
}

\begin{abstract}
Acoustic technologies have the potential to be used as a surrogate for measuring suspendedsediment concentration (SSC). This potential was examined in a fine-grained (97-100 percent fines) riverine system in central Illinois by way of installation of an acoustic instrument. Acoustic data were collected continuously over the span of 5.5 years. Acoustic parameters were regressed against SSC data to determine the accuracy of using acoustic technology as a surrogate for measuring SSC in a finegrained riverine system. The resulting regressions for SSC and sediment acoustic parameters had coefficients of determination ranging from 0.75 to 0.97 for various events and configurations. The overall Nash-Sutcliffe model-fit efficiency was 0.95 for the 132 observed and predicted SSC values determined using the sediment acoustic parameter regressions. The study of using acoustic technologies as a surrogate for measuring SSC in fine-grained riverine systems is ongoing. The results at this site are promising in the realm of surrogate technology.
\end{abstract}

\section{Introduction}

Acoustic technology is increasingly being used for river velocity measurements, and similar to turbidity sensors, the potential for acoustic parameters to also be used as a surrogate for suspendedsediment concentration (SSC) would be an added benefit. However, by 2008, limited acoustic data with matching SSC samples had been collected on stream systems with predominantly fine-grained sediments, where fine-grained is defined to be any particle size smaller than 0.0625 millimeters (mm). For that reason, the U.S. Geological Survey (USGS) installed an acoustic instrument at the gaging station on Kickapoo Creek at Bloomington, Illinois (USGS streamgage 05579630) in 2009 to test advanced sediment surrogate monitoring technologies and methodologies.

Sediment data collection at the Kickapoo Creek site was part of a larger monitoring project funded by the Illinois Environmental Protection Agency (Roseboom and Straub, 2013). Sediments are transported by drainage ditches from approximately 9,000 acres of agricultural row crops throughout the watershed and from a 480-acre housing development at the southwest end of the watershed (fig. 1). The sediments are predominantly clays and silts that are 97-100 percent fines (appendix 1), so this was an ideal site to test the use of an acoustic Doppler velocity meter (ADVM) as a surrogate for estimating suspended sediment in a fine-grained riverine system. Because hysteresis in sediment concentration of the hydrograph is a regular occurrence (fig. 2a, 2b), advanced surrogates like sediment acoustic parameters may provide a more accurate estimate of suspended-sediment concentration (fig. 2c, 2d). Certain streamflow conditions cause the shear stress to be higher on the rising limb than on the falling 
limb of the hydrograph, causing larger sediment transport on the rising limb than on the falling limb at a given flow depth (Julien, 2002). Variation in peak concentration from one hydrograph to the next is also common (fig. 2a) and likely due to sediment supply in the watershed and creek.

\section{Purpose and Scope}

The purpose of this report is to analyze the use of acoustic technology as a surrogate for SSC in a fine-grained riverine system, Kickapoo Creek at Bloomington, Illinois. At this site, the sediment in the system is predominantly clays and silts that are 97-100 percent fines (appendix 1). A fixed mount uplooking ADVM was installed and collected acoustic data during four different time periods, and a mobile down-looking acoustic Doppler current profiler (ADCP) was used in tandem with the ADVM during one of the time periods for collecting concurrent data.

\section{Methods}

A fixed mount up-looking ADVM Sontek Argonaut-SW (3,000 kilohertz (kHz)) (Sontek, 2009) was installed to provide acoustic data as surrogate measurements for SSC. A mobile down-looking ADCP—a Teledyne RD Instruments (TRDI) Rio Grande (1200 kHz) (Teledyne RD Instruments, 2007) - also was used to collect acoustic information during one of the same storm events as the ADVM. Unlike turbidity, which uses a single measured value near the instrument, the acoustic method uses measured values from multiple cells along the acoustic axis of the beam in the calculation of the acoustic parameters for use as a surrogate. For the method used in this study, the sediment concentration and grain size characteristics within the acoustic measurement volume are assumed to either be homogeneous or have only variations that offset and do not affect the average value (Landers and others, 2016). In general, this method is applied only to side-looking instruments where this assumption is more likely to be true. However, because of the predominantly fine-grained particles in Kickapoo Creek at Bloomington, IL, the suspended sediment is well mixed in the vertical water column and so this assumption is likely to be valid for up-looking instruments here as well. Some of the earliest USGS applications and research were done with side-looking acoustic instruments by Topping and others (2004, 2006, 2007), Wright and others (2010), Landers (2011), Wood and Teasdale (2013), Wood and others (2015), and Landers and others (2016).

Collecting discrete SSC samples for a wide range of stream conditions is important in order to develop strong relations with surrogate values. Sampling and laboratory methods used for discrete SSC samples are described by Edwards and Glysson (1999) and Sholar and Shreve (1998). The samples collected at this site were sent to the USGS Kentucky Water Science Center Sediment Lab for processing. For this study, automatic pumping samples and equal width increment (EWI) samples were the primary types of samples used. Point and single vertical samples were collected for the April 22, 2011, storm event in which the ADCP also was collecting data and will be discussed later in the report. Nine of the 132 discrete samples were collected using EWI sampling methods. These samples helped determine box coefficients (ratio of the EWI and pump sample concentration value) for the study (Porterfield, 1972). The box coefficients ranged from 0.88 to 1.18 with a mean of 0.99 and a standard deviation of 0.10 . These results show that the system is well mixed and that the pump sample concentration values can be used without adjustment. The SSC values from all of the samples were then used to create linear regressions of SSC and acoustic parameters to determine the accuracy of using acoustic instruments as surrogates for measuring SSC. A detailed discussion on how the linear regressions were developed is available in Landers and others (2016). 


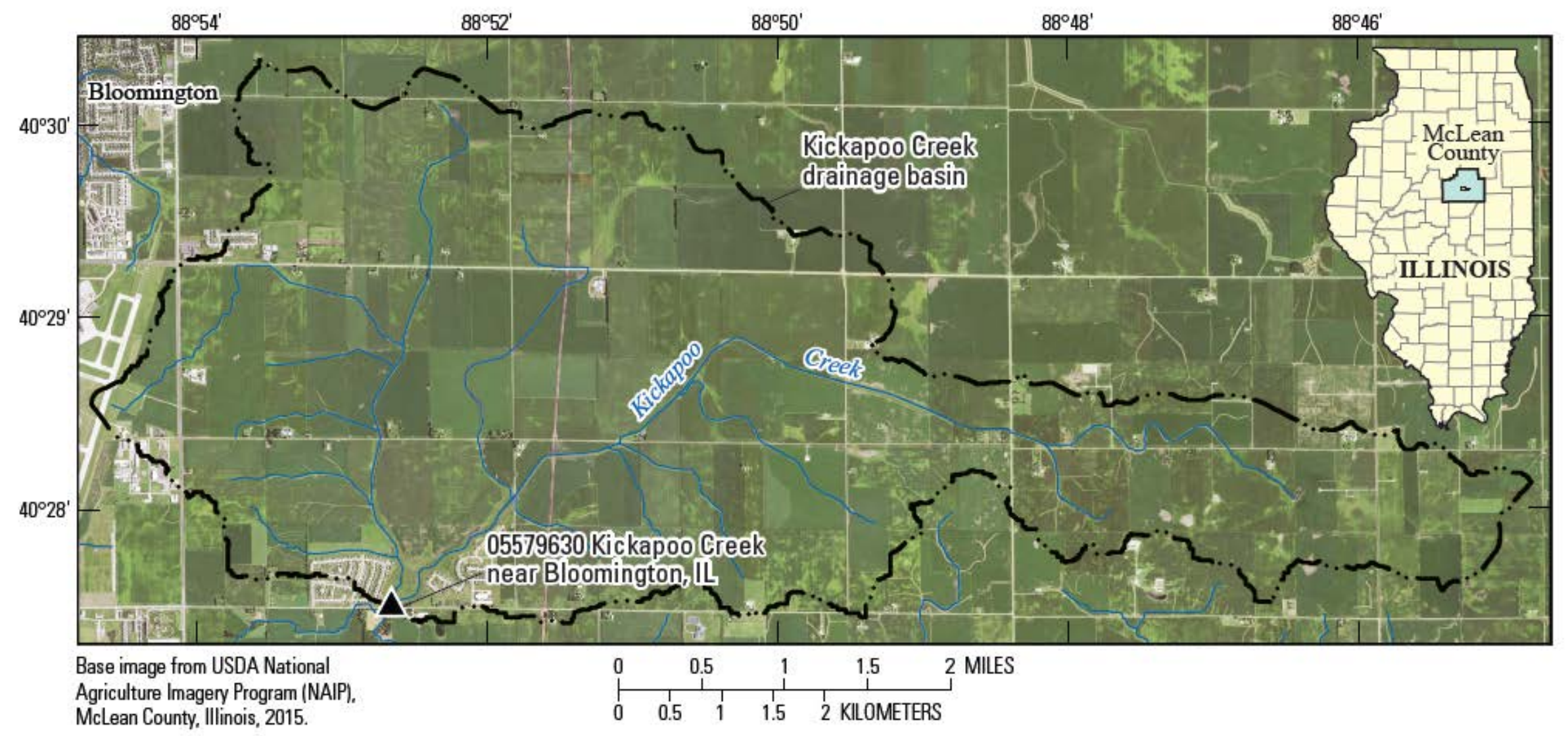

Figure 1. Map of the Kickapoo Creek drainage basin and location of U.S. Geological Survey streamgage 05579630 Kickapoo Creek at Bloomington, Illinois. 

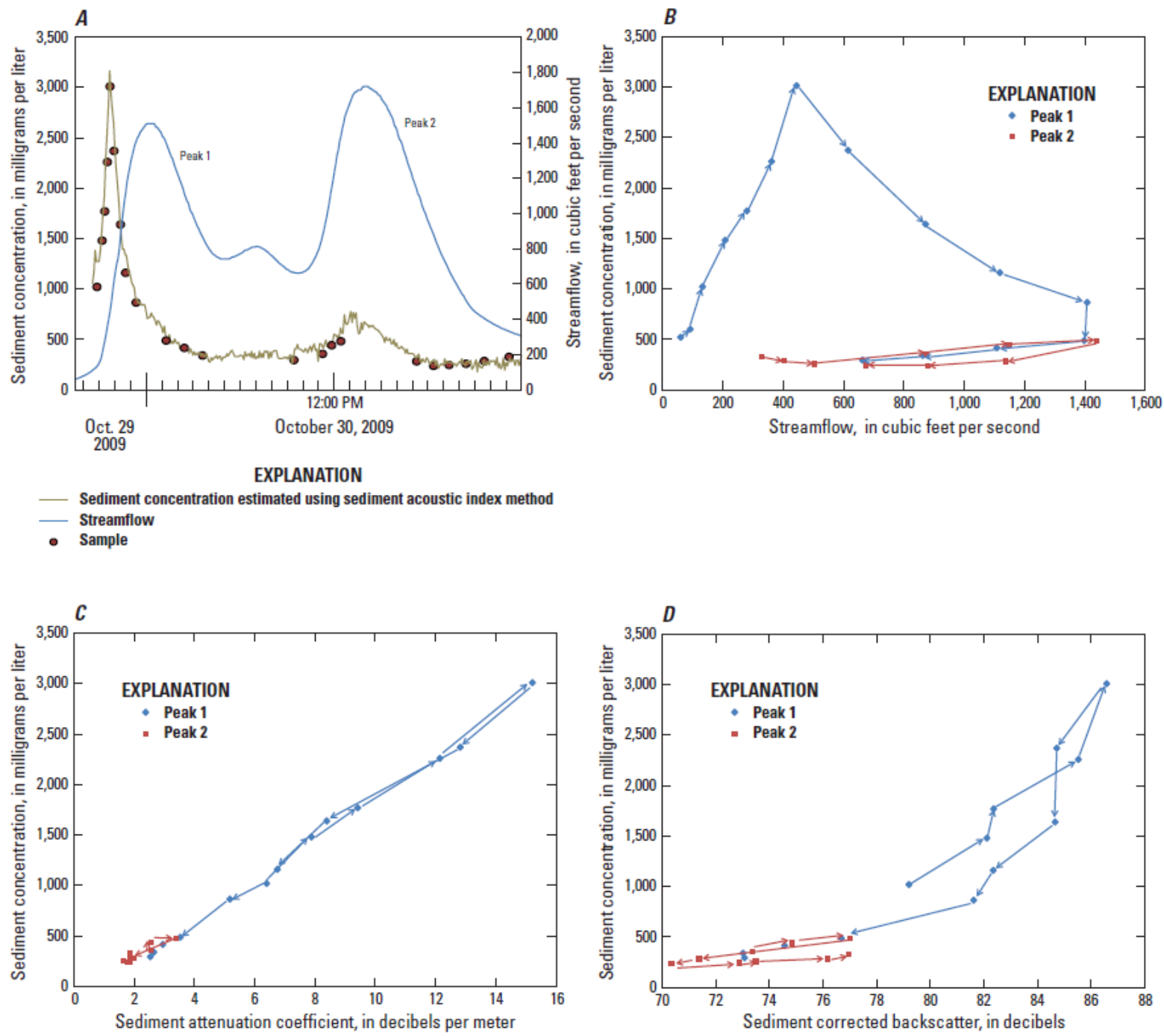

Figure 2. (A) Streamflow and suspended-sediment concentrations from samples and estimated using the sediment acoustic index method during a storm event on Kickapoo Creek at Bloomington, Illinois (U.S. Geological Survey streamgage 05579630). (B) Relation and hysteresis between streamflow and SSC samples. (C) and (D) Relation between sediment acoustic parameters and suspended-sediment concentration samples (from Landers and others, 2016).

\section{Sediment Acoustic Index Rating Development}

From October 9, 2009, through July 9, 2015, 132 discrete SSC samples were used for linear regression model building with sediment acoustic parameters. SSC values were matched with the acoustic parameter whose sample time was closest to that of the SSC sample time within a range of 5 minutes. A relation between SSC (response variable) and acoustic parameters (explanatory variable) was developed using an ordinary least squares (OLS) linear regression. With a linear regression, observed data are fit to a linear model and terms in the model, such as the slope and y-intercept, are estimated (Helsel and Hirsch, 2002). The statistics for the data and models are discussed in the following sections. 


\section{Linear Regression Models - Acoustic Doppler Velocity Meter}

The data matching, sediment acoustic processing, and linear regression modeling were completed using the Surrogate Analysis and Index Developer (SAID) tool (Domanski and others, 2015). Linear regression models for SSC as the response variable were developed with the calculated acoustic parameters for four different ADVM configurations (3000-1, 3000-2, 3000-3, and 3000-4) and time periods (table 1). Four different configurations were used in an attempt to optimize the data collection process. Because of varying cell sizes and blanking distances among the configurations, a separate model was developed for each configuration (fig. 3-5, table 2, 3). Full model statistics are included in appendices 2-5. The SSC values used in the linear models ranged from 85 to 3,320 milligrams per liter $(\mathrm{mg} / \mathrm{L})$, which encompasses a broad range of flow conditions that occurred during the study period (table 2). During all four ADVM configurations, many discrete suspended sediment samples were missing coincident continuous acoustic observations and were therefore not used in the regressions.

Table 1. Acoustic Doppler velocity meter configurations during study period.

[ADVM, acoustic Doppler velocity meter; kHz, kilohertz; m, meters; SNR, signal-to-noise ratio; Amp, backscatter amplitude; RSSI, received signal strength indicator; WCB, water-corrected backscatter]

\begin{tabular}{|c|c|c|c|c|c|c|c|}
\hline Configuration $^{1}$ & Start date & End date & $\begin{array}{c}\text { Frequency } \\
\text { (kHz) }\end{array}$ & Range of cells & $\begin{array}{c}\text { Cell size } \\
(\mathbf{m})\end{array}$ & $\begin{array}{c}\text { Blanking } \\
\text { distance }(\mathbf{m})\end{array}$ & $\begin{array}{c}\text { Beam } \\
\text { number }\end{array}$ \\
\hline ADVM 3000-1 & $10 / 6 / 2009$ & $12 / 8 / 2009$ & 3,000 & $1-5$ & 0.30 & 0.30 & 2 \\
\hline ADVM 3000-2 & 4/22/2011 & 4/22/2011 & 3,000 & $2-5$ & 0.20 & 0.07 & Average \\
\hline ADVM 3000-3 & 4/16/2013 & 8/9/2013 & 3,000 & $2-3$ & 0.57 & 0.25 & Average \\
\hline ADVM 3000-4 & $1 / 1 / 2015$ & 8/7/2015 & 3,000 & $2-10$ & 0.20 & 0.25 & Average \\
\hline
\end{tabular}

${ }^{1}$ Backscatter values (SNR, Amp, RSSI) = Amp; Intensity scale factor (if using Amp) = 0.43; Slant beam angle (in degrees) = 45; Effective transducer diameter $(\mathrm{m})=0.015$; Near-field correction = yes; WCB profile adjustment = yes; Moving average span $=1$.

To determine the best linear models, different combinations of untransformed and $\log _{10^{-}}$ transformed variables (for example, SSC, acoustic parameters, streamflow, and gage height) were evaluated (appendix 2). Explanatory and response variable statistics for the best SSC and acoustic parameter linear regression models are available in table 2 . The best linear models were selected by looking at multiple model statistics, including the residuals, the coefficient of determination $\left(R^{2}\right)$, and the adjusted $R^{2}$ value. The SSC was plotted separately against the sediment attenuation coefficient (SAC) and the average sediment-corrected backscatter (MeanSCB) for all four configurations (fig. 3). The SAC is the acoustic energy loss per unit distance, and the MeanSCB is the average of the portion of measured backscatter after correcting for transmission losses (Landers and others, 2016). The sediment acoustic parameters SAC and MeanSCB were generally better explanatory variables than streamflow and gage height. Although the multiple linear regression calculated for configuration 4 (appendix 2) slightly improved the adjusted $R^{2}$ value, the focus of this section is on the individual results of using SAC and MeanSCB separately as explanatory variables. The best models and residuals are plotted for the SAC and MeanSCB for each configuration (figs. 4 and 5). The residuals of SSC are the difference, in $\mathrm{mg} / \mathrm{L}$, between predicted and observed SSC, and the residuals of the $\log _{10}$-transformation of SSC are the difference between predicted and observed values of the $\log _{10}$-transformation of SSC.

Although most of the data in figures $4 A$ and $B$ are relatively linear, there is observed scatter in the 2015 data that also was apparent when regressing SSC with data from two turbidity meters that were 
installed at the site (appendix 6). This indicates that it is less likely that the scatter in 2015 was caused by the different ADVM configuration.

Overall the OLS fit describes a high proportion of variance in the models, as evidenced by the $R^{2}$ values, and the residuals of the regressions are homoscedastic, which is an assumption of the OLS fit. Homoscedasticity indicates a constant variation in the residuals (Helsel and Hirsch, 2002).
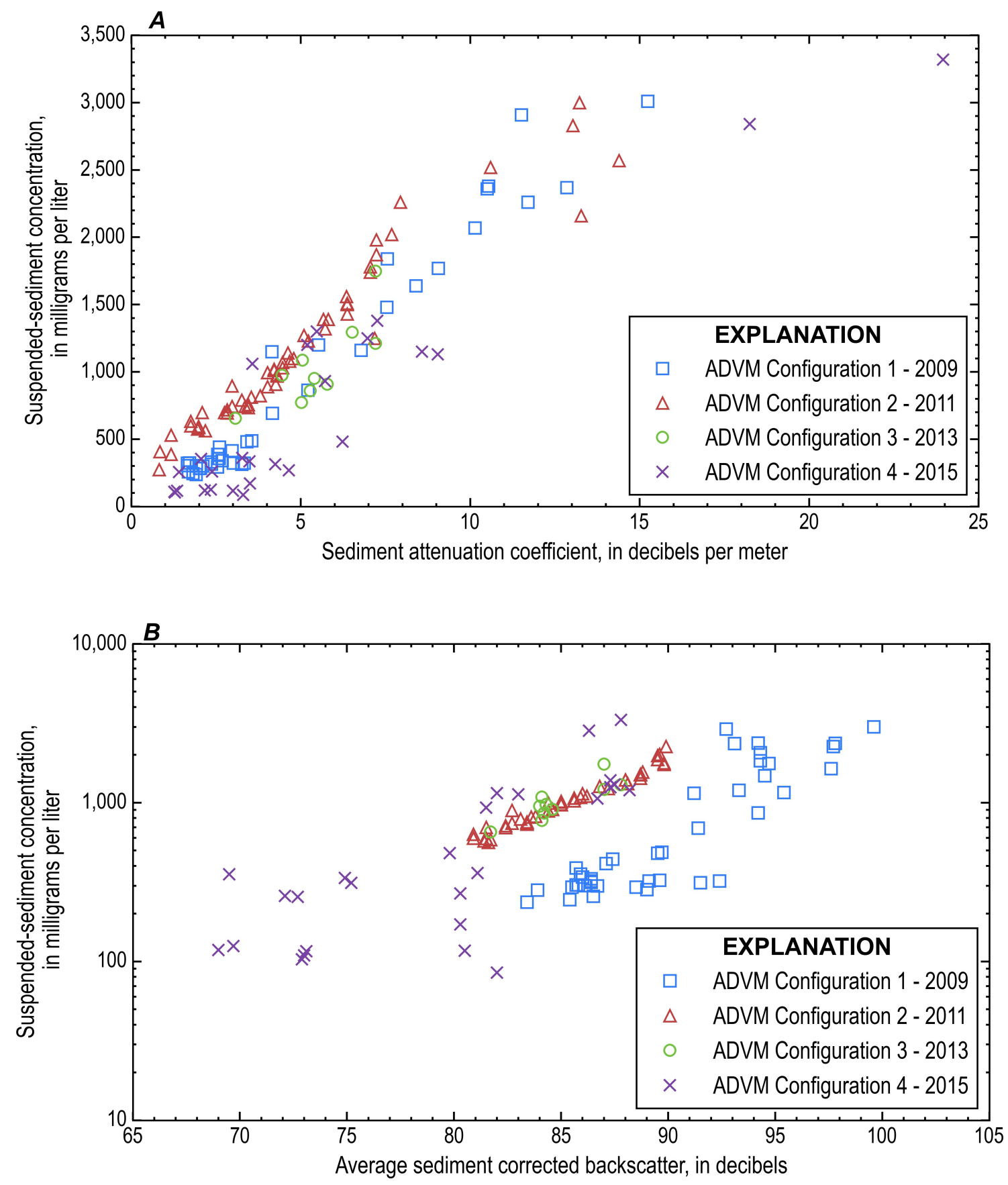

Figure 3. (A) Scatter plots of all available data. Relation between suspended-sediment concentration and the sediment attenuation coefficient, and $(B)$ relation between suspended-sediment concentration and average sediment corrected backscatter. 

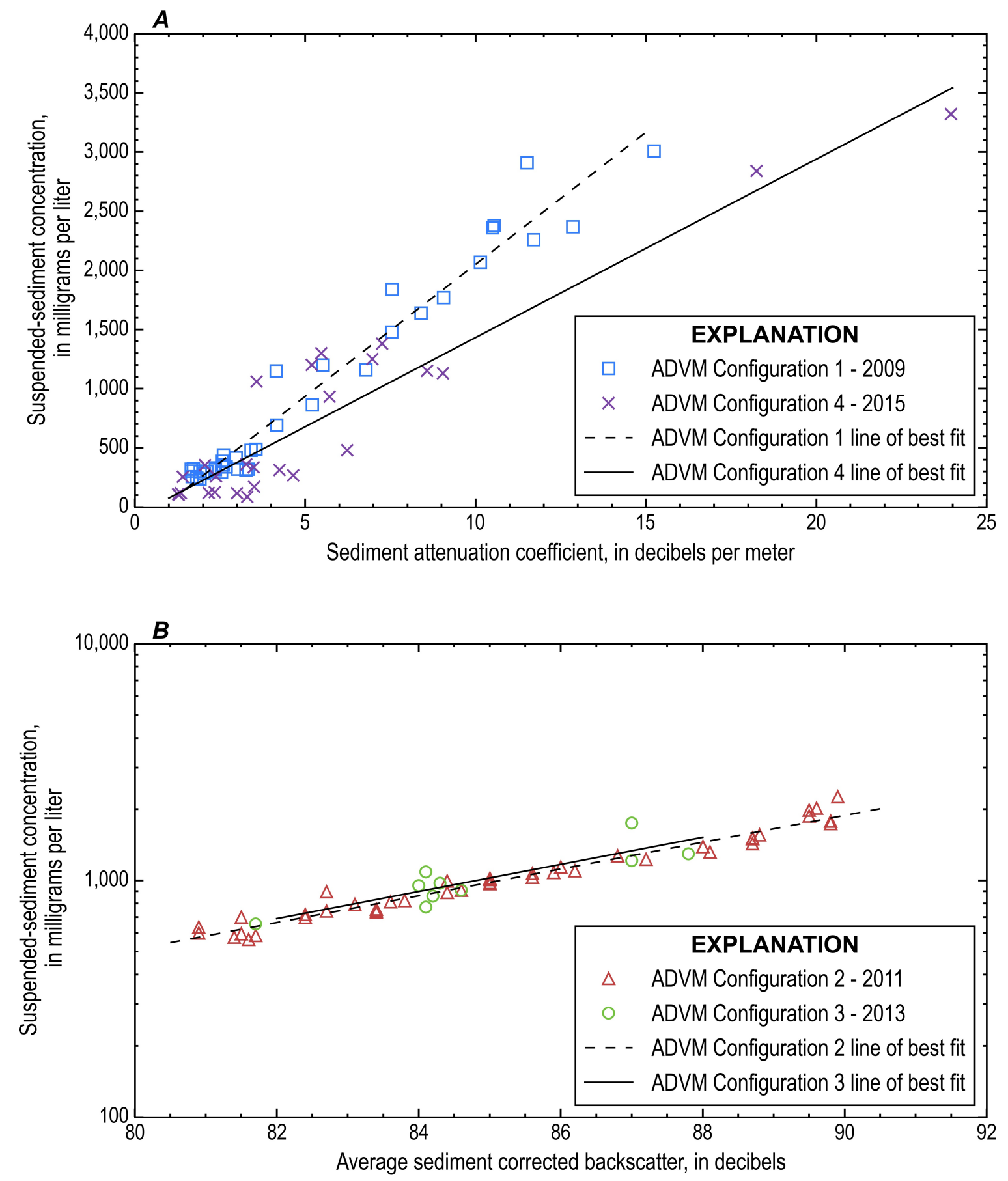

Figure 4. (A) Linear regressions of suspended-sediment concentration versus sediment attenuation coefficient, and $(B)$ base-10 logarithmic transformed suspended-sediment concentration versus average sediment corrected backscatter in Kickapoo Creek, Illinois, 2009-15. 

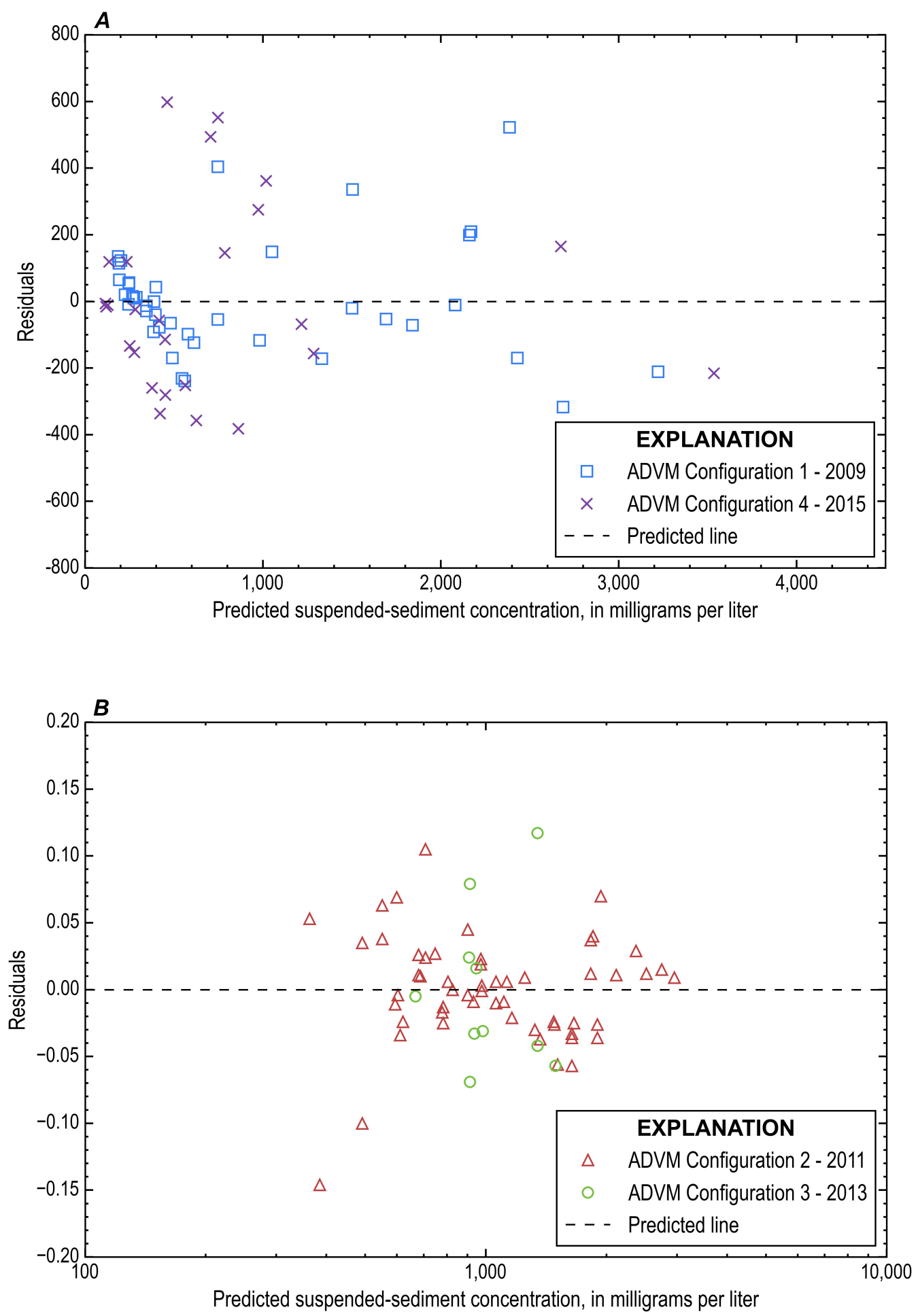

Figure 5. (A) Regression residuals of the predicted suspended-sediment concentration versus sediment attenuation coefficient, and $(B)$ predicted base-10 logarithmic transformed suspended-sediment concentration versus average sediment corrected backscatter in Kickapoo Creek, Illinois, 2009-15. 
Table 2. Explanatory and response variable statistics for the best suspended-sediment concentration and acoustic parameter linear regression models.

[ADVM, acoustic Doppler velocity meter; $\log _{10}$, base-10 logarithmic transform; SSC, suspended-sediment concentration; mg/L, milligrams per liter; $\mathrm{dB}$, decibels; $\mathrm{dB} / \mathrm{m}$, decibels per meter; SAC, sediment attenuation coefficient; MeanSCB, average sediment corrected backscatter]

\begin{tabular}{|c|c|c|c|}
\hline Configuration & Explanatory variable & \multicolumn{2}{|c|}{$\begin{array}{c}\text { Response } \\
\text { variable }\end{array}$} \\
\hline ADVM 3000-1 & $\mathrm{SAC}(\mathrm{dB} / \mathrm{m})$ & SSC (mg/L) & \\
\hline Minimum & 1.65 & 237 & \\
\hline 1st Quartile & 2.09 & 304 & \\
\hline Median & 3.01 & 388 & \\
\hline Mean & 4.90 & 913 & \\
\hline 3rd Quartile & 7.54 & 1,520 & \\
\hline Maximum & 15.2 & 3,010 & \\
\hline ADVM $3000-2$ & MeanSCB (dB) & $\mathrm{SSC}(\mathrm{mg} / \mathrm{L})$ & $\log _{10}(S S C)$ \\
\hline Minimum & 77.9 & 274 & 2.4378 \\
\hline 1st Quartile & 82.5 & 722 & 2.8585 \\
\hline Median & 85.0 & 1,010 & 3.0043 \\
\hline Mean & 85.4 & 1,182 & 3.0146 \\
\hline 3rd Quartile & 88.7 & 1,483 & 3.1709 \\
\hline Maximum & 92.9 & 3,000 & 3.4771 \\
\hline ADVM $3000-3$ & MeanSCB (dB) & $\mathrm{SSC}$ (mg/L) & $\log _{10}(S S C)$ \\
\hline Minimum & 81.7 & 654 & 2.8156 \\
\hline 1st Quartile & 84.1 & 859 & 2.9340 \\
\hline Median & 84.3 & 963 & 2.9834 \\
\hline Mean & 84.9 & 1,046 & 3.0036 \\
\hline 3rd Quartile & 87.0 & 1,211 & 3.0831 \\
\hline Maximum & 87.8 & 1,747 & 3.2423 \\
\hline ADVM $3000-4$ & $\mathrm{SAC}(\mathrm{dB} / \mathrm{m})$ & $\mathrm{SSC}(\mathrm{mg} / \mathrm{L})$ & \\
\hline Minimum & 1.27 & 85 & \\
\hline 1st Quartile & 2.35 & 125 & \\
\hline Median & 3.54 & 345 & \\
\hline Mean & 5.38 & 736 & \\
\hline 3rd Quartile & 6.23 & 1,150 & \\
\hline Maximum & 24.0 & 3,320 & \\
\hline
\end{tabular}


The best regression models for each configuration of the ADVM are presented in table 3. Because SSC was transformed for the regression against MeanSCB, the predicted mean of the variable may be biased and needs to be multiplied by a nonparametric smearing bias correction factor (BCF) (Duan, 1983; Helsel and Hirsch, 2002) (table 3). The BCF is used to account for retransformation bias and is determined from the model residuals (Landers and others, 2016). These equations were used to predict SSC and plot with observed SSC around a line of perfect agreement (fig. 6). The overall modelfit efficiency (Nash and Sutcliffe, 1970) between 132 observed and predicted SSC values was 0.95. Model-fit efficiencies that are greater than 0.9 indicate a close match between measured and predicted SSC.

Table 3. Suspended-sediment concentration and acoustic parameter linear regression models, coefficients of determination, and nonparametric smearing bias correction factor for the best model in each configuration.

[SSC, suspended-sediment concentration; SAC, sediment attenuation coefficient; MeanSCB, average sediment corrected backscatter; $\mathrm{R}^{2}$, coefficient of determination; BCF, nonparametric smearing bias correction factor; ADVM, acoustic Doppler velocity meter; ---, not applicable]

\begin{tabular}{|c|c|c|c|}
\hline Configuration & Linear regression model & $\mathbf{R}^{2}$ & BCF \\
\hline \multicolumn{4}{|c|}{ SSC versus SAC } \\
\hline ADVM 3000-1 & $\mathrm{SSC}=-182+223 \times \mathrm{SAC}$ & 0.96 & --- \\
\hline ADVM 3000-4 & $\mathrm{SSC}=-75.9+151 \times \mathrm{SAC}$ & 0.89 & --- \\
\hline \multicolumn{4}{|c|}{ SSC versus MeanSCB } \\
\hline ADVM 3000-2 & $\mathrm{SSC}=0.007244 \times 10^{0.0604 \mathrm{MeanSCB}} \times \mathrm{BCF}$ & 0.97 & 1.0043 \\
\hline ADVM 3000-3 & $\mathrm{SSC}=0.014454 \times 10^{0.0571 \text { MeanSCB }} \times \mathrm{BCF}$ & 0.75 & 1.0433 \\
\hline
\end{tabular}




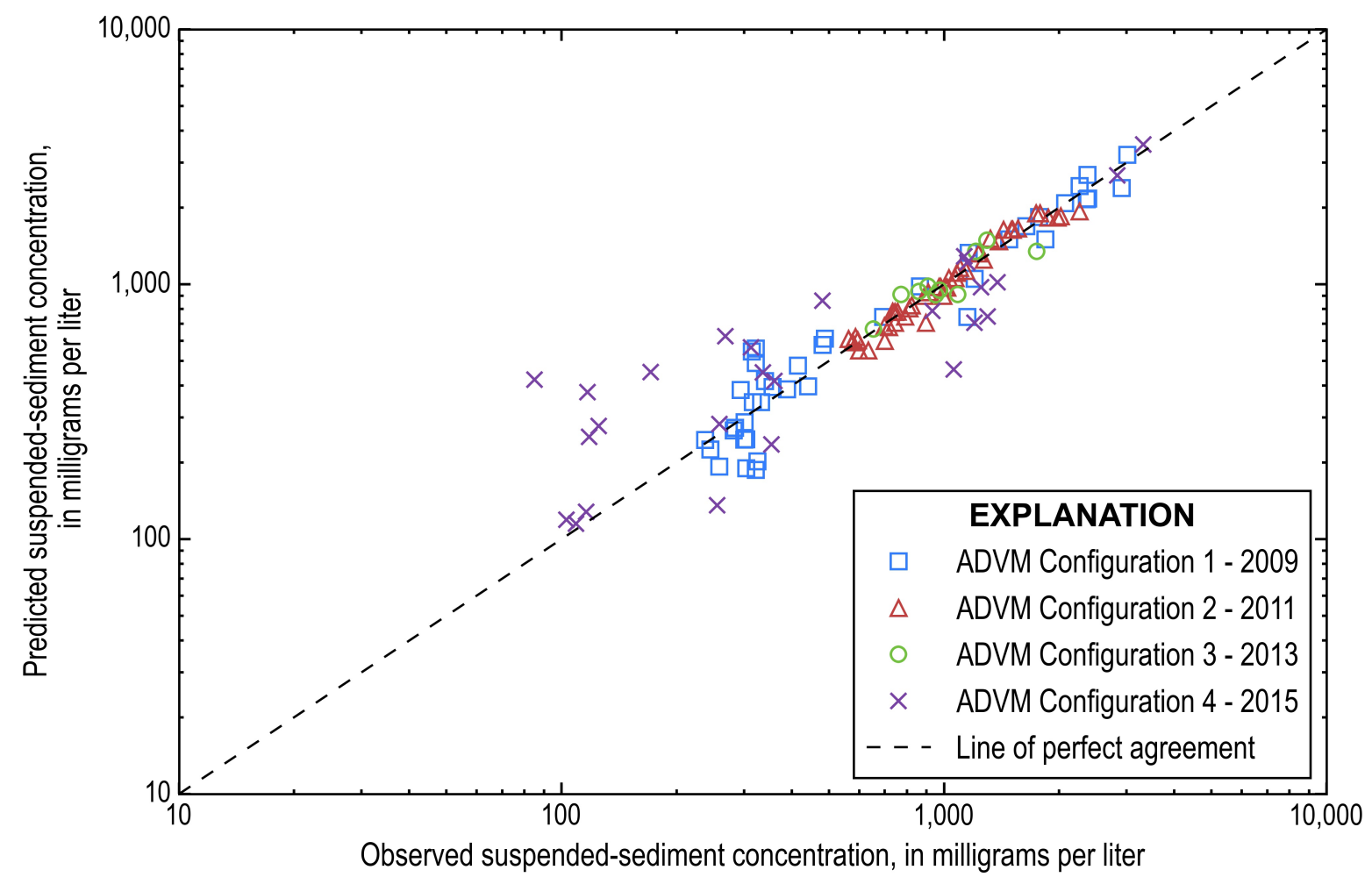

Figure 6. Predicted and observed suspended-sediment concentration from the best model for each configuration. The predicted concentration was found using acoustic parameter linear regression models.

\section{Linear Regression Model - Acoustic Doppler Current Profiler}

A mobile down-looking ADCP recorded discrete measurements during a storm event on April 22, 2011. The main differences between the ADCP and ADVM are the mobility of the down-looking ADCP and the scope of the measurements that are taken. The ADVM is fixed to the riverbed, profiles vertically through the water column (bottom to top), and operates continuously; the ADCP is traversed on the water surface by way of a trimaran (either along a transect or in a stationary location), profiles vertically through the water column (top to bottom), and operates for discrete time periods.

The sediment acoustic processing for the ADCP data was completed using a tool discussed in Boldt (2015), but followed the same methods as used in the SAID tool for this scenario. Information on the configuration during this time is available in table 4. Linear regression models with SSC as the response variable were developed with the calculated acoustic parameters for a single ADCP configuration (1200-1) using the SAID tool (table 4). The SSC values used in the linear models ranged from 563 to 2,260 mg/L (table 4). Although this does not encompass the entire range of conditions seen at this site (table 2), it does demonstrate a large range of conditions that occur in a span of less than 24 hours. 
Table 4. (A) Acoustic Doppler current meter configuration during study period. (B) Explanatory and response variable statistics for the best suspended-sediment concentration and acoustic parameter linear regression model. (C) Suspended-sediment concentration and acoustic parameter linear regression model, coefficient of determination, and non-parametric smearing bias correction factor for the best model in this configuration.

[kHz, kilohertz; m, meters; SSC, suspended-sediment concentration; MeanSCB, average sediment corrected backscatter; log 10 , base-10 logarithmic transform; $\mathrm{mg} / \mathrm{L}$, milligrams per liter; $\mathrm{dB}$, decibels; $\mathrm{R}^{2}$, coefficient of determination; $\mathrm{BCF}$, nonparametric smearing bias correction factor; ADCP, acoustic Doppler current profiler]

(A)

\begin{tabular}{ccccccc}
\hline & & & & & & Cell size \\
$(\mathbf{m})$ & $\begin{array}{c}\text { Blanking } \\
\text { distance }(\mathbf{m})\end{array}$ \\
\hline Configuration & Start date & End date & Range of cells & $14-21$ & 0.04 & 0.25 \\
\hline
\end{tabular}

(B)

\begin{tabular}{|l|c|cc|}
\hline \multicolumn{1}{|c|}{ Configuration } & $\begin{array}{c}\text { Explanatory } \\
\text { variable }\end{array}$ & \multicolumn{2}{|c|}{$\begin{array}{c}\text { Response } \\
\text { variable }\end{array}$} \\
\hline \multicolumn{1}{|c|}{ ADCP 1200-1 } & MeanSCB (dB) & $\log _{10}$ (SSC) & SSC (mg/L) \\
\hline Minimum & 82.4 & 2.7505 & 563 \\
1st Quartile & 84.3 & 2.8713 & 744 \\
Median & 86.8 & 3.0011 & 1,003 \\
Mean & 87.0 & 3.0098 & 1,100 \\
3rd Quartile & 89.4 & 3.1430 & 1,390 \\
Maximum & 93.0 & 3.3541 & 2,260 \\
\hline
\end{tabular}

(C)

\begin{tabular}{|c|c|c|c|}
\hline Configuration & Linear regression model & $\mathbf{R}^{2}$ & $\mathrm{BCF}$ \\
\hline \multicolumn{4}{|c|}{ SSC versus MeanSCB } \\
\hline ADCP $1200-1$ & $\mathrm{SSC}=0.021380 \times 10^{0.0538 \mathrm{MeanSCB}} \times \mathrm{BCF}$ & 0.98 & 1.0018 \\
\hline
\end{tabular}

Despite the differences in the mobility and scope of measurements between the ADVM and the ADCP, the regression equations predict SSC values that are similar as shown in fig. 7. When the discrete SSC values predicted by the ADCP data and SSC samples are plotted with the continuous ADVM data (fig. 8), the ADCP data and SSC samples lie within the 90 percent prediction interval of the SSC predicted values from ADVM data. This is another demonstration of the similarities between the data collected by the two instruments.

A statistical comparison of the data from the ADCP and the data from the ADVM was done by an analysis of covariance (ANCOVA). The ANCOVA is essentially a crossover between a linear regression and an analysis of variance (Helsel and Hirsch, 2002). Based on the ANCOVA, there is a distinct model for ADCP acoustic data and a distinct model for ADVM acoustic data. The ANCOVA was done using a 99 percent confidence interval $(\alpha=0.01)$. The null hypotheses of the whole model and intercept tests were rejected, while the null hypothesis of the slope test was not rejected. This demonstrates that the two models are distinct and have different intercepts, but it is assumed that they have the same slope. 

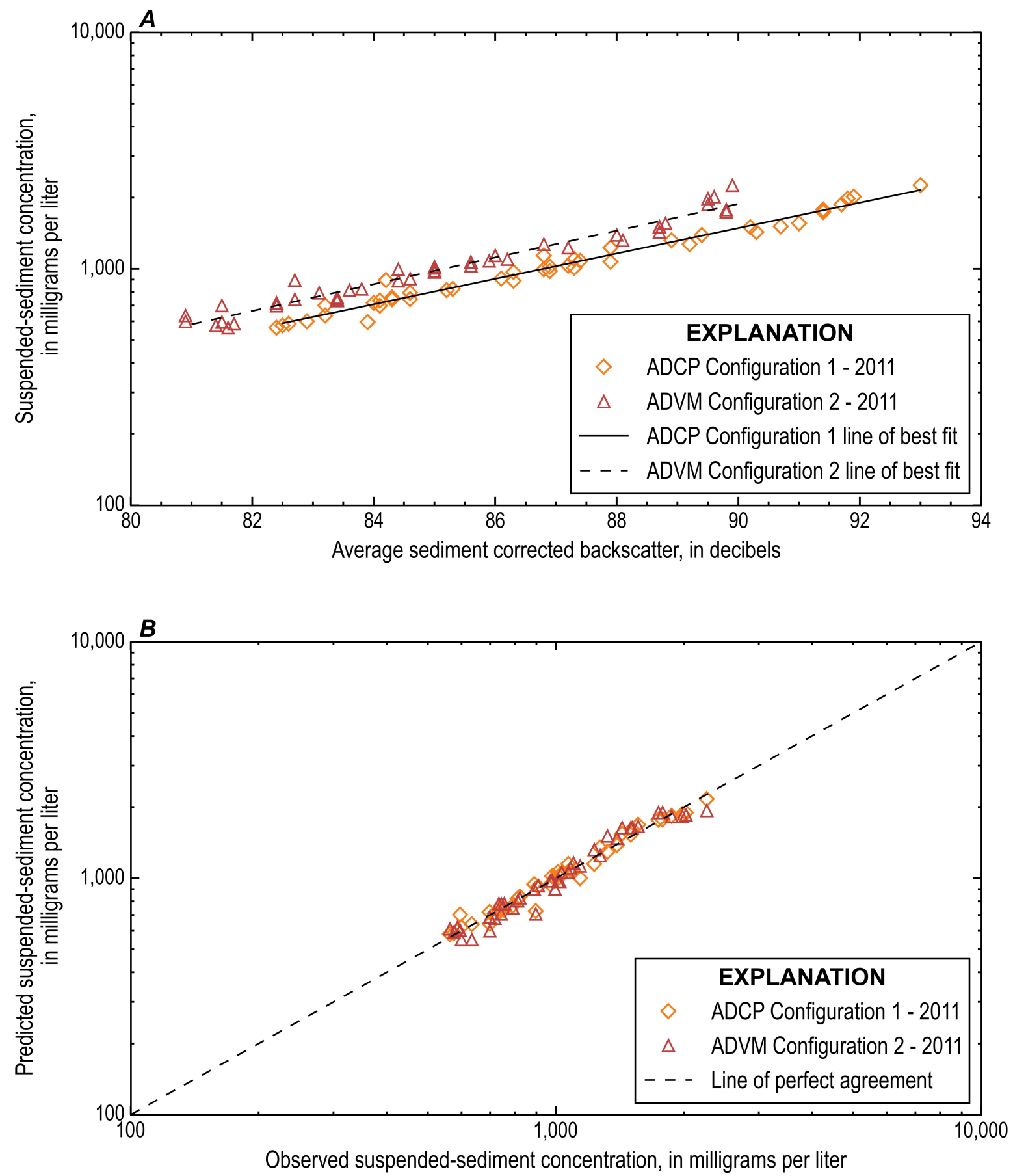

Figure 7. (A) Linear regressions of base-10 logarithmic transformed suspended-sediment concentration versus average sediment corrected backscatter for the ADCP and ADVM to show parallels between the two instruments. (B) Predicted and observed suspended-sediment concentration from the best model in 2011 for each instrument. 


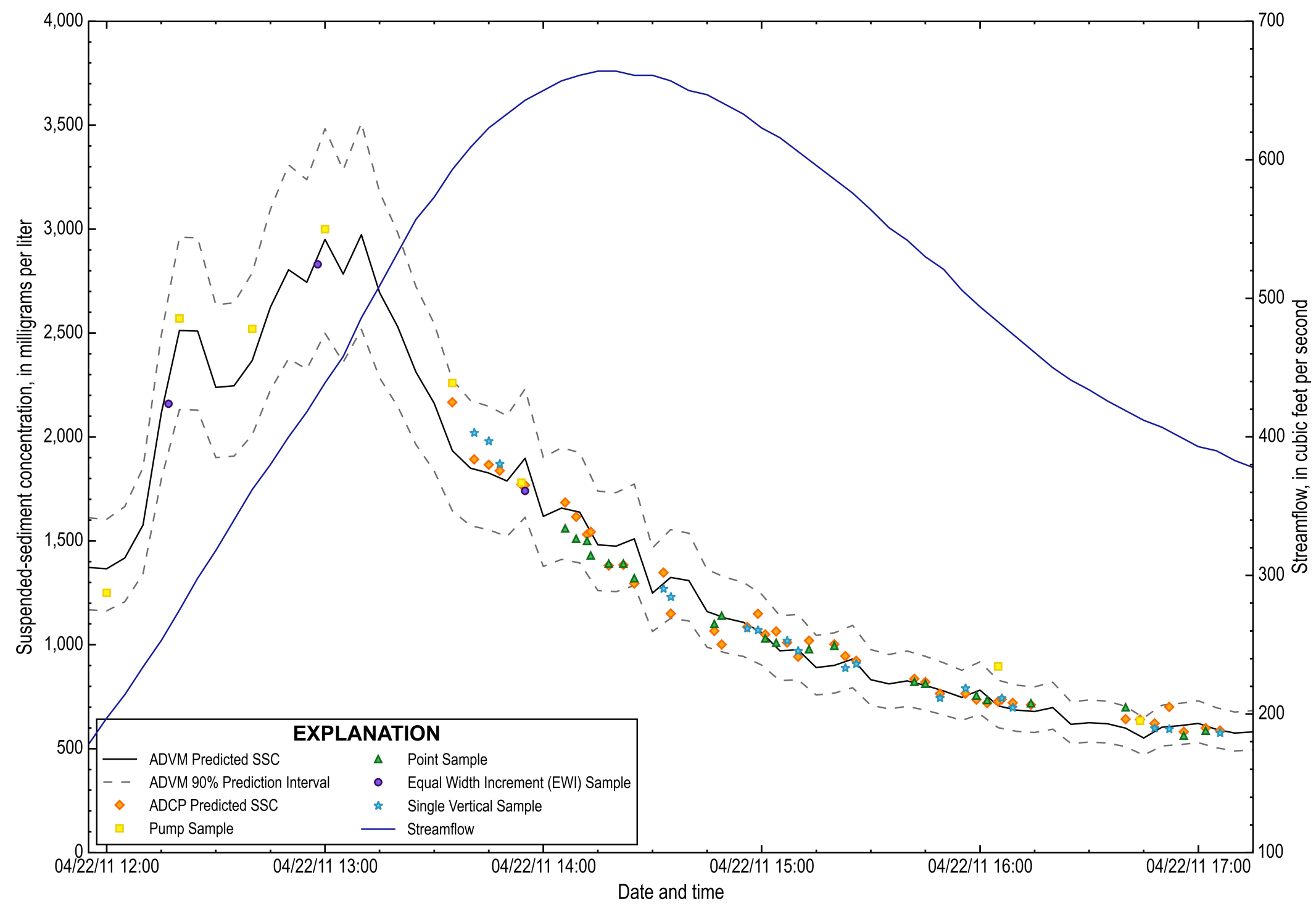

Figure 8. A plot of streamflow at the site in cubic feet per second, acoustic Doppler velocity meter (ADVM) and acoustic Doppler current profiler (ADCP) predicted suspended-sediment concentration, and actual suspended-sediment concentration values. The predicted values from the ADCP and the actual values lie within the ADVM ninety percent prediction interval. 


\section{Summary}

The use of acoustic technology as a surrogate for estimating suspended-sediment concentration (SSC) was examined at a U.S. Geological Survey stream-gaging site on Kickapoo Creek in central Illinois that transports predominantly fine-grained sediments (97-100 percent fines). This report provides an analysis of using acoustic technology to determine SSC in a fine-grained riverine system. A fixed mount up-looking acoustic Doppler velocity meter (ADVM) was installed and collected acoustic data during four different time periods; a mobile down-looking acoustic Doppler current profiler (ADCP) also collected data in tandem with the ADVM during one of those time periods.

From October 9, 2009, through July 9, 2015, 132 discrete SSC samples were collected and used for linear regression model building with sediment acoustic parameters. The SSC values ranged from 85 to 3,320 milligrams per liter, which encompasses a broad range of flow conditions that occurred during the study period. Relations between SSC and acoustic parameters were found using an ordinary least squares (OLS) linear regression.

The OLS fit describes a high proportion of variance in the models, as evidenced by the coefficient of determination $\left(R^{2}\right)$ values, and the residuals of the regressions are homoscedastic, which is an assumption of the OLS fit. The resulting regressions for SSC and sediment acoustic parameters had coefficients of determinations ranging from 0.75 to 0.97 for various events and configurations. The overall Nash-Sutcliffe model-fit efficiency was 0.95 for 132 observed and predicted SSC values determined using the sediment acoustic parameters regressions from the ADVM. When the discrete SSC values predicted by the ADCP data and SSC samples are plotted with the continuous ADVM data for the event in 2011, the ADCP data and SSC samples lie within the 90 percent prediction interval of the SSC predicted values from ADVM data. Additional research is needed on the effect of the acoustic instrument configuration and resulting regression coefficients, but the results of this study indicate that acoustic technologies have the potential to be used as a surrogate for SSC in a stream transporting predominantly fine-grained sediment.

\section{References Cited}

Boldt, J.A., 2015, From mobile ADCP to high-resolution SSC-a cross-section calibration tool: 10th Federal Interagency Sedimentation Conference, Reno, Nev., April 19-23, 2015, 3 p.

Domanski, M.M., Straub, T.D., and Landers, M.N., 2015, Surrogate analysis and index developer (SAID) tool (version 1.0, September 2015): U.S. Geological Survey Open-File Report 2015-1177, 38 p., accessed June 8, 2016, at http://dx.doi.org/10.3133/ofr20151177.

Duan, N., 1983, Smearing estimate-a nonparametric retransformation method: Journal of the American Statistical Society, v. 78, p. 605-610.

Edwards, T.K., and Glysson, G.D., 1999, Field methods for measurement of fluvial sediment: U.S. Geological Survey Techniques of Water-Resources Investigations Report, Applications of Hydraulics, book 3, chap. C2, 89 p.

Helsel, D.R., and Hirsch, R.M., 2002, Statistical methods in water resources-hydrologic analysis and interpretation: U.S. Geological Survey Techniques of Water-Resources Investigations, book 4, chap. A3, 510 p.

Julien, P.Y., 2002, River mechanics: New York, Cambridge University Press, 434 p.

Landers, M.N., 2011, Fluvial suspended sediment characteristics by high-resolution, surrogate metrics of turbidity, laser-diffraction, acoustic backscatter, and acoustic attenuation: Atlanta, Georgia Institute of Technology, Ph.D. dissertation, 236 p., accessed June 14, 2012, at http://hdl.handle.net/1853/43747. 
Landers, M.N., Straub, T.D., Wood, M.S., and Domanski, M.M., 2016, Sediment acoustic index method for computing continuous suspended-sediment concentrations: U.S. Geological Survey Techniques and Methods, book 3, chap. C5, 124 p.

Nash, J.E., and Sutcliffe, J.V., 1970, River flow forecasting through conceptual models, Part 1-A discussion of principles: Journal of Hydrology, v. 10, p. 282-290.

Porterfield, G., 1972, Computation of fluvial-sediment discharge: U.S. Geological Survey Techniques of Water-Resources Investigations, book 3, chap. C3, 71 p.

Roseboom, D.P., and Straub, T.D., 2013, Monitoring of green infrastructure at The Grove in Bloomington, Illinois: U.S. Geological Survey Fact Sheet 2013-3048, 4 p. [Accessed at http://pubs.usgs.gov/fs/2013/3048/.]

Sholar, C.J., and Shreve, E.A., 1998, Quality-assurance plan for the analysis of fluvial sediment by the Northeastern Region, Kentucky District Sediment Laboratory: U.S. Geological Survey Open-File Report 98-384, 20 p. [Accessed at https://pubs.er.usgs.gov/publication/ofr98384.]

Sontek-YSI Incorporated, 2009, Argonaut-SW system manual firmware, version 12.0: Sontek-YSI Incorporated, San Diego, Calif., 310 p.

Teledyne RD Instruments, 2007, Workhorse Rio Grande ADCP user's guide: Teledyne RD Instruments, San Diego, Calif., 28 p.

Topping, D.J., Melis, T.S., Rubin, D.M., and Wright, S.A., 2004, High-resolution monitoring of suspended-sediment concentration and grain size in the Colorado River in Grand Canyon using a laser acoustic system, in Proceedings of the 9th International Symposium on River Sedimentation: Yichang, China, October 18-21, Tsinghua University Press, p. 2507-2514.

Topping, D.J., Wright, S.A., Melis, T.S., and Rubin, D.M., 2006, High-resolution monitoring of suspended-sediment concentration and grain size in the Colorado River using laser-diffraction instruments and a three-frequency acoustic system, in Proceedings of the 8th Federal Inter-Agency Sedimentation Conference: Reno, Nev., April 2-6, 2006, p. 555-559.

Topping, D.J., Wright, S.A., Melis, T.S. and Rubin, D.M., 2007, High-resolution measurement of suspended-sediment concentrations and grain size in the Colorado River in Grand Canyon using a multi-frequency acoustic system, in Proceedings of the 10th International Symposium on River Sedimentation: Moscow, Russia, August 1-4, p. 330-339.

Wood, M.S., Fosness, R.L., and Etheridge, A.B., 2015, Sediment transport and evaluation of sediment surrogate ratings in the Kootenai River near Bonners Ferry, Idaho, water years 2011-14: U.S. Geological Survey Scientific Investigations Report 2015-5169, 48 p., accessed June 8, 2016, at http://dx.doi.org/10.3133/sir20155169.

Wood, M.S., and Teasdale, G.N., 2013, Use of surrogate technologies to estimate suspended sediment in the Clearwater River, Idaho, and Snake River, Washington, 2008-10: U.S. Geological Survey Scientific Investigations Report 2013-5052, 30 p.

Wright, S.A., Topping, D.J., and Williams, C.A., 2010, Discriminating silt-and-clay from suspendedsand in rivers using side-looking acoustic profilers: 2nd Joint Federal Interagency Conference, Las Vegas, NV, June 27-July 1, 12 p. 
Appendix 1. Particle size distribution at U.S. Geological Survey stream-gaging site 05579630 on Kickapoo Creek at Bloomington, Illinois

\begin{tabular}{|c|c|c|c|c|c|c|c|c|c|}
\hline \multirow[b]{2}{*}{ Sample date and time } & \multicolumn{9}{|c|}{ Percent of particles with diameter smaller than indication size, in micrometers } \\
\hline & $<2$ & $2-4$ & $<8$ & $8-16$ & $16-32$ & $<62.5$ & $62.5-125$ & $125-250$ & $250-500$ \\
\hline 10/23/2009 3:00 & & & & & & 98 & & & \\
\hline 10/23/2009 4:15 & & & & & & 99 & 99 & 100 & \\
\hline 10/23/2009 9:44 & & & & & & 97 & 99 & 99 & 100 \\
\hline 10/23/2009 11:11 & & & & & & 98 & & & \\
\hline 10/29/2009 21:45 & & & & & & 98 & & & \\
\hline 10/29/2009 22:25 & 51 & 59 & 66 & 78 & 94 & 96 & 98 & 99 & 100 \\
\hline 10/29/2009 23:25 & & & & & & 95 & & & \\
\hline 10/30/2009 1:20 & & & & & & 98 & 99 & 99 & 100 \\
\hline 4/19/2011 11:19 & & & 75 & 91 & 98 & 98 & 100 & & \\
\hline 4/22/2011 13:45 & 59 & 67 & 73 & 83 & 95 & 99 & 100 & & \\
\hline 4/22/2011 14:09 & 51 & 65 & 79 & 92 & 97 & 99 & 100 & & \\
\hline 4/22/2011 14:13 & 50 & 65 & 78 & 90 & 97 & 99 & 100 & & \\
\hline 4/22/2011 14:18 & 51 & 65 & 78 & 91 & 97 & 99 & 100 & & \\
\hline 4/22/2011 14:25 & 51 & 66 & 79 & 91 & 97 & 99 & 100 & & \\
\hline 4/22/2011 14:49 & 53 & 67 & 79 & 92 & 99 & 99 & 100 & & \\
\hline 4/22/2011 14:59 & & & & & & 98 & 99 & 99 & 100 \\
\hline 4/22/2011 15:42 & 59 & 73 & 83 & 91 & 98 & 99 & 100 & & \\
\hline 4/22/2011 15:45 & 59 & 73 & 84 & 93 & 99 & 99 & 100 & & \\
\hline 4/22/2011 15:56 & & & & & & 99 & 99 & 100 & \\
\hline 4/22/2011 16:09 & & & & & & 98 & 98 & 99 & 100 \\
\hline 4/22/2011 16:56 & 62 & 75 & 84 & 94 & 98 & 99 & 100 & & \\
\hline 4/22/2011 17:06 & 65 & 74 & 87 & 88 & 96 & 98 & 98 & 99 & 100 \\
\hline
\end{tabular}




\begin{tabular}{cccccccccc}
\hline & \multicolumn{8}{c}{ Percent of particles with diameter smaller than indication size, in micrometers } \\
Sample date and time & $<\mathbf{2}$ & $\mathbf{2 - 4}$ & $\mathbf{<}$ & $\mathbf{8 - 1 6}$ & $\mathbf{1 6 - 3 2}$ & $<\mathbf{6 2 . 5}$ & $\mathbf{6 2 . 5 - 1 2 5}$ & $\mathbf{1 2 5 - 2 5 0}$ & $\mathbf{2 5 0 - 5 0 0}$ \\
\hline $4 / 18 / 201310: 19$ & 55 & 72 & 78 & 86 & 92 & 100 & & \\
$4 / 18 / 201313: 50$ & 57 & 65 & 71 & 79 & 87 & 99 & 100 \\
$4 / 18 / 201313: 56$ & 65 & 75 & 77 & 92 & 99 & 100 & & \\
\hline
\end{tabular}




\section{Appendix 2. Model Statistics Summary}

The shaded results are the best models that are described in the main body of the report.

[SSC, suspended-sediment concentration; MeanSCB, average sediment corrected backscatter; $\log _{10}$, base-10 logarithmic transform; SAC, sediment attenuation coefficient; Q, streamflow in cubic feet per second; GH, gage height in feet; $\mathrm{R}^{2}$, coefficient of determination; adj ${ }^{2}$, adjusted coefficient of determination; RMSE, root mean squared error; VIF, variance inflation factor, ---, not applicable]

\begin{tabular}{|c|c|c|c|c|c|c|c|c|c|c|c|c|c|c|c|c|c|}
\hline \multirow{2}{*}{$\begin{array}{c}\text { Response } \\
\text { variable }\end{array}$} & \multirow{2}{*}{$\begin{array}{l}\text { Explanatory } \\
\text { variable(s) }\end{array}$} & \multicolumn{4}{|c|}{$\begin{array}{c}\text { Configuration } 1 \\
41 \text { samples }\end{array}$} & \multicolumn{4}{|c|}{$\begin{array}{c}\text { Configuration } 2 \\
55 \text { samples }\end{array}$} & \multicolumn{4}{|c|}{$\begin{array}{c}\text { Configuration } 3 \\
10 \text { samples }\end{array}$} & \multicolumn{4}{|c|}{$\begin{array}{c}\text { Configuration } 4 \\
26 \text { samples }\end{array}$} \\
\hline & & $\mathbf{R}^{2}$ & $\operatorname{adjR}^{2}$ & RMSE & VIF & $\mathbf{R}^{2}$ & $\operatorname{adjR}^{2}$ & RMSE & VIF & $\mathbf{R}^{2}$ & $\operatorname{adjR}^{2}$ & RMSE & VIF & $\mathbf{R}^{2}$ & $\operatorname{adjR}^{2}$ & RMSE & VIF \\
\hline SSC & meanSCB & 0.69 & 0.68 & 484 & --- & 0.89 & 0.89 & 210 & --- & 0.68 & 0.64 & 187 & --- & 0.49 & 0.47 & 603 & --- \\
\hline $\log _{10} \mathrm{SSC}$ & meanSCB & 0.78 & 0.77 & 0.180 & --- & 0.97 & 0.97 & 0.041 & --- & 0.75 & 0.72 & 0.064 & --- & 0.58 & 0.57 & 0.318 & --- \\
\hline $\log _{10} \mathrm{SSC}$ & $\log _{10}$ meanSCB & 0.77 & 0.77 & 0.181 & --- & 0.97 & 0.97 & 0.041 & --- & 0.75 & 0.72 & 0.064 & --- & 0.57 & 0.55 & 0.323 & --- \\
\hline SSC & $\log _{10}$ meanSCB & 0.68 & 0.67 & 489 & --- & 0.88 & 0.88 & 222 & --- & 0.68 & 0.64 & 187 & --- & 0.48 & 0.46 & 612 & --- \\
\hline SSC & SAC & 0.96 & 0.96 & 171 & --- & 0.92 & 0.92 & 178 & --- & 0.66 & 0.61 & 194 & --- & 0.89 & 0.88 & 283 & --- \\
\hline $\log _{10} \mathrm{SSC}$ & SAC & 0.90 & 0.90 & 0.118 & --- & 0.85 & 0.84 & 0.090 & --- & 0.72 & 0.68 & 0.068 & --- & 0.59 & 0.57 & 0.317 & --- \\
\hline $\log _{10} \mathrm{SSC}$ & $\log _{10} \mathrm{SAC}$ & 0.94 & 0.94 & 0.091 & --- & 0.94 & 0.94 & 0.057 & --- & 0.67 & 0.63 & 0.074 & --- & 0.73 & 0.72 & 0.256 & --- \\
\hline SSC & $\log _{10} \mathrm{SAC}$ & 0.90 & 0.90 & 275 & --- & 0.81 & 0.80 & 283 & --- & 0.59 & 0.54 & 212 & --- & 0.74 & 0.73 & 429 & --- \\
\hline SSC & $\mathrm{Q}$ & 0.02 & 0.00 & 749 & --- & 0.38 & 0.37 & 625 & --- & 0.21 & 0.19 & 652 & --- & 0.14 & 0.13 & 550 & --- \\
\hline $\log _{10} \mathrm{SSC}$ & $\mathrm{Q}$ & 0.08 & 0.07 & 0.392 & --- & 0.62 & 0.62 & 0.413 & --- & 0.31 & 0.30 & 0.522 & --- & 0.21 & 0.19 & 0.446 & --- \\
\hline $\log _{10} \mathrm{SSC}$ & $\log _{10} \mathrm{Q}$ & 0.22 & 0.21 & 0.363 & --- & 0.71 & 0.71 & 0.363 & --- & 0.59 & 0.58 & 0.403 & --- & 0.38 & 0.37 & 0.395 & --- \\
\hline SSC & $\log _{10} \mathrm{Q}$ & 0.10 & 0.08 & 718 & --- & 0.39 & 0.38 & 619 & --- & 0.35 & 0.34 & 590 & --- & 0.25 & 0.24 & 515 & --- \\
\hline SSC & $\mathrm{GH}$ & 0.08 & 0.07 & 725 & --- & 0.40 & 0.40 & 611 & --- & 0.34 & 0.33 & 594 & --- & 0.25 & 0.24 & 515 & --- \\
\hline $\log _{10} \mathrm{SSC}$ & $\mathrm{GH}$ & 0.19 & 0.18 & 0.369 & --- & 0.72 & 0.72 & 0.357 & --- & 0.56 & 0.55 & 0.419 & --- & 0.35 & 0.34 & 0.403 & --- \\
\hline $\log _{10} \mathrm{SSC}$ & $\log _{10} \mathrm{GH}$ & 0.23 & 0.22 & 0.360 & --- & 0.73 & 0.73 & 0.349 & --- & 0.61 & 0.60 & 0.393 & --- & 0.38 & 0.37 & 0.394 & --- \\
\hline SSC & $\log _{10} \mathrm{GH}$ & 0.11 & 0.09 & 715 & --- & 0.39 & 0.39 & 617 & --- & 0.37 & 0.36 & 581 & --- & 0.25 & 0.24 & 514 & --- \\
\hline $\log _{10} \mathrm{SSC}$ & meanSCB, SAC & 0.91 & 0.91 & 0.113 & 4.2 & 0.97 & 0.97 & 0.041 & 2.3 & 0.77 & 0.70 & 0.067 & 7.2 & 0.73 & 0.71 & 0.262 & 1.6 \\
\hline SSC & meanSCB, SAC & 0.96 & 0.96 & 166 & 4.2 & 0.95 & 0.95 & 150 & 2.3 & 0.70 & 0.61 & 195 & 7.2 & 0.92 & 0.91 & 249 & 1.6 \\
\hline $\log _{10} \mathrm{SSC}$ & meanSCB, Q & 0.78 & 0.77 & 0.182 & 1.0 & 0.97 & 0.97 & 0.042 & 1.3 & 0.77 & 0.71 & 0.066 & 2.7 & 0.58 & 0.55 & 0.328 & 1.1 \\
\hline $\log _{10} \mathrm{SSC}$ & meanSCB, $\log _{10} \mathrm{Q}$ & 0.78 & 0.77 & 0.180 & 1.0 & 0.97 & 0.97 & 0.041 & 1.3 & 0.77 & 0.70 & 0.066 & 2.2 & 0.59 & 0.55 & 0.327 & 1.1 \\
\hline SSC & SAC, Q & 0.96 & 0.96 & 173 & 1.1 & 0.94 & 0.93 & 164 & 1.0 & 0.77 & 0.70 & 171 & 1.8 & 0.96 & 0.95 & 184 & 1.0 \\
\hline SSC & SAC, $\log _{10} \mathrm{Q}$ & 0.96 & 0.96 & 173 & 1.1 & 0.94 & 0.94 & 162 & 1.0 & 0.78 & 0.71 & 168 & 1.5 & 0.96 & 0.96 & 171 & 1.0 \\
\hline $\log _{10} \mathrm{SSC}$ & meanSCB, GH & 0.78 & 0.77 & 0.180 & 1.1 & 0.97 & 0.97 & 0.041 & 1.2 & 0.77 & 0.71 & 0.066 & 2.2 & 0.58 & 0.55 & 0.328 & 1.1 \\
\hline
\end{tabular}




\begin{tabular}{|c|c|c|c|c|c|c|c|c|c|c|c|c|c|c|c|c|c|}
\hline \multirow{2}{*}{$\begin{array}{c}\text { Response } \\
\text { variable }\end{array}$} & \multirow{2}{*}{$\begin{array}{c}\text { Explanatory } \\
\text { variable(s) }\end{array}$} & \multicolumn{4}{|c|}{$\begin{array}{c}\text { Configuration } 1 \\
41 \text { samples }\end{array}$} & \multicolumn{4}{|c|}{$\begin{array}{c}\text { Configuration } 2 \\
55 \text { samples }\end{array}$} & \multicolumn{4}{|c|}{$\begin{array}{c}\text { Configuration } 3 \\
10 \text { samples }\end{array}$} & \multicolumn{4}{|c|}{$\begin{array}{c}\text { Configuration } 4 \\
26 \text { samples }\end{array}$} \\
\hline & & $\mathbf{R}^{2}$ & $\mathrm{adj}^{2}$ & RMSE & VIF & $\mathbf{R}^{2}$ & $\operatorname{adjR}^{2}$ & RMSE & VIF & $\mathbf{R}^{2}$ & $\operatorname{adjR}^{2}$ & RMSE & VIF & $\mathbf{R}^{2}$ & $\operatorname{adj}^{2}$ & RMSE & VIF \\
\hline $\log _{10} \mathrm{SSC}$ & meanSCB, $\log _{10} \mathrm{GH}$ & 0.78 & 0.77 & 0.179 & 1.1 & 0.97 & 0.97 & 0.041 & 1.2 & 0.77 & 0.71 & 0.066 & 2.0 & 0.58 & 0.55 & 0.328 & 1.1 \\
\hline SSC & SAC, GH & 0.96 & 0.96 & 173 & 1.1 & 0.94 & 0.94 & 162 & 1.0 & 0.78 & 0.71 & 167 & 1.5 & 0.96 & 0.96 & 171 & 1.0 \\
\hline SSC & $\mathrm{SAC}, \log _{10} \mathrm{GH}$ & 0.96 & 0.96 & 172 & 1.1 & 0.94 & 0.94 & 162 & 1.0 & 0.78 & 0.72 & 167 & 1.4 & 0.96 & 0.96 & 177 & 1.0 \\
\hline
\end{tabular}




\section{Appendix 3. Sediment Attenuation Coefficient Data}

[SAC, sediment attenuation coefficient; mg/L, milligrams per liter; SSC, suspended-sediment concentration; dB/m, decibels per meter; log 10 , base-10 logarithmic transform; EWI, equal width increment; DFFITS, difference in fit statistic; CST, Central (U.S.) standard time; ---, not applicable]

\begin{tabular}{|c|c|c|c|c|c|c|c|c|c|c|}
\hline \multicolumn{4}{|c|}{ Suspended sediment } & \multirow{2}{*}{$\begin{array}{c}\begin{array}{c}\text { Acoustic } \\
\text { parameter }\end{array} \\
\text { SAC } \\
(\mathrm{dB} / \mathrm{m}) \\
\end{array}$} & \multicolumn{6}{|c|}{ Rating information } \\
\hline $\begin{array}{l}\text { Date and time } \\
\text { (CST) }\end{array}$ & $\begin{array}{c}\text { Sample } \\
\text { type }\end{array}$ & $\begin{array}{l}\text { Samp } \\
\text { concent } \\
(\mathrm{mg} / \mathrm{L})\end{array}$ & $\begin{array}{l}\text { le } \\
\text { ation } \\
\log _{10} \\
\end{array}$ & & $\begin{array}{c}\text { Predicted SSC } \\
(\mathrm{mg} / \mathrm{L})\end{array}$ & Residual & $\begin{array}{c}\text { Normal } \\
\text { Quantiles }\end{array}$ & Leverage & Cook's D & DFFITS \\
\hline \multicolumn{11}{|l|}{2009 ADVM Data } \\
\hline $10 / 23 / 20095: 50$ & Pump Sample & 1150 & 3.06 & 4.15 & 746 & 404.2 & 1.764 & 0.025 & 0.075 & 0.414 \\
\hline 10/23/2009 2:10 & Pump Sample & 2070 & 3.32 & 10.14 & 2081 & -10.6 & 0.061 & 0.073 & 0.000 & -0.018 \\
\hline 10/23/2009 2:25 & Pump Sample & 2360 & 3.37 & 10.50 & 2161 & 199.0 & 1.218 & 0.080 & 0.064 & 0.361 \\
\hline 10/23/2009 2:40 & Pump Sample & 2910 & 3.46 & 11.51 & 2387 & 522.6 & 2.182 & 0.102 & 0.592 & 1.255 \\
\hline 10/23/2009 3:00 & Pump Sample & 2380 & 3.38 & 10.54 & 2170 & 209.6 & 1.357 & 0.081 & 0.072 & 0.383 \\
\hline 10/23/2009 3:30 & Pump Sample & 1840 & 3.26 & 7.55 & 1504 & 336.2 & 1.529 & 0.037 & 0.077 & 0.409 \\
\hline 10/23/2009 4:15 & Pump Sample & 1200 & 3.08 & 5.52 & 1051 & 148.9 & 1.099 & 0.025 & 0.010 & 0.141 \\
\hline 10/23/2009 5:30 & Pump Sample & 692 & 2.84 & 4.16 & 746 & -54.2 & -0.309 & 0.025 & 0.001 & -0.051 \\
\hline 10/23/2009 8:35 & Pump Sample & 388 & 2.59 & 2.55 & 388 & 0.0 & 0.184 & 0.034 & 0.000 & 0.000 \\
\hline 10/23/2009 9:44 & EWI & 316 & 2.50 & 2.36 & 345 & -28.8 & -0.122 & 0.036 & 0.001 & -0.033 \\
\hline 10/23/2009 9:45 & Pump Sample & 332 & 2.52 & 2.36 & 345 & -12.8 & 0.000 & 0.036 & 0.000 & -0.015 \\
\hline 10/23/2009 10:00 & Pump Sample & 301 & 2.48 & 2.11 & 288 & 12.5 & 0.309 & 0.038 & 0.000 & 0.015 \\
\hline 10/23/2009 11:05 & Pump Sample & 304 & 2.48 & 1.92 & 247 & 57.1 & 0.652 & 0.040 & 0.002 & 0.069 \\
\hline 10/23/2009 11:11 & EWI & 300 & 2.48 & 1.92 & 246 & 53.5 & 0.578 & 0.040 & 0.002 & 0.065 \\
\hline 10/23/2009 11:25 & Pump Sample & 304 & 2.48 & 1.66 & 190 & 114.3 & 0.811 & 0.043 & 0.011 & 0.144 \\
\hline 10/23/2009 12:40 & Pump Sample & 322 & 2.51 & 1.65 & 187 & 135.3 & 0.994 & 0.043 & 0.015 & 0.171 \\
\hline 10/23/2009 14:05 & Pump Sample & 294 & 2.47 & 2.54 & 385 & -91.4 & -0.652 & 0.034 & 0.005 & -0.102 \\
\hline 10/23/2009 15:50 & Pump Sample & 322 & 2.51 & 3.01 & 491 & -169.3 & -0.994 & 0.031 & 0.016 & -0.179 \\
\hline 10/29/2009 21:15 & Pump Sample & 1480 & 3.17 & 7.54 & 1501 & -20.5 & -0.061 & 0.037 & 0.000 & -0.024 \\
\hline 10/29/2009 21:25 & Pump Sample & 1770 & 3.25 & 9.06 & 1841 & -71.0 & -0.440 & 0.055 & 0.005 & -0.102 \\
\hline 10/29/2009 21:35 & Pump Sample & 2260 & 3.35 & 11.70 & 2430 & -169.9 & -1.099 & 0.106 & 0.066 & -0.364 \\
\hline 10/29/2009 21:45 & Pump Sample & 3010 & 3.48 & 15.24 & 3221 & -210.9 & -1.357 & 0.214 & 0.265 & -0.737 \\
\hline 10/29/2009 22:00 & Pump Sample & 2370 & 3.37 & 12.85 & 2687 & -316.9 & -2.182 & 0.137 & 0.316 & -0.828 \\
\hline 10/29/2009 22:25 & Pump Sample & 1640 & 3.21 & 8.40 & 1692 & -52.4 & -0.246 & 0.046 & 0.002 & -0.068 \\
\hline
\end{tabular}




\begin{tabular}{|c|c|c|c|c|c|c|c|c|c|c|}
\hline \multicolumn{4}{|c|}{ Suspended sediment } & $\begin{array}{l}\text { Acoustic } \\
\text { parameter }\end{array}$ & \multicolumn{6}{|c|}{ Rating information } \\
\hline $\begin{array}{l}\text { Date and time } \\
\text { (CST) }\end{array}$ & $\begin{array}{c}\text { Sample } \\
\text { type }\end{array}$ & $\begin{array}{l}\text { Samp } \\
\text { concentr } \\
(\mathrm{mg} / \mathrm{L})\end{array}$ & $\begin{array}{l}e \\
\text { ation } \\
\log _{10} \\
\end{array}$ & $\begin{array}{c}\mathrm{SAC} \\
(\mathrm{dB} / \mathrm{m})\end{array}$ & $\begin{array}{c}\text { Predicted SSC } \\
(\mathrm{mg} / \mathrm{L})\end{array}$ & & Cook's D & DFFITS \\
\hline 10/29/2009 22:45 & Pump Sample & 1160 & 3.06 & 6.78 & 1331 & -171.4 & -1.218 & 0.031 & 0.016 & -0.181 \\
\hline 10/29/2009 23:25 & Pump Sample & 865 & 2.94 & 5.21 & 981 & -116.5 & -0.811 & 0.025 & 0.006 & -0.109 \\
\hline 10/30/2009 1:20 & EWI & 488 & 2.69 & 3.55 & 612 & -123.8 & -0.898 & 0.028 & 0.008 & -0.123 \\
\hline 10/30/2009 2:30 & Pump Sample & 415 & 2.62 & 2.97 & 480 & -65.3 & -0.374 & 0.031 & 0.002 & -0.069 \\
\hline 10/30/2009 3:40 & Pump Sample & 340 & 2.53 & 2.68 & 417 & -77.3 & -0.508 & 0.033 & 0.004 & -0.084 \\
\hline 10/30/2009 9:30 & Pump Sample & 294 & 2.47 & 2.54 & 385 & -91.0 & -0.578 & 0.034 & 0.005 & -0.101 \\
\hline 10/30/2009 11:20 & Pump Sample & 356 & 2.55 & 2.59 & 396 & -39.6 & -0.184 & 0.034 & 0.001 & -0.044 \\
\hline 10/30/2009 11:55 & Pump Sample & 441 & 2.64 & 2.60 & 398 & 43.3 & 0.508 & 0.034 & 0.001 & 0.048 \\
\hline 10/30/2009 12:30 & Pump Sample & 481 & 2.68 & 3.41 & 579 & -97.9 & -0.729 & 0.028 & 0.005 & -0.099 \\
\hline 10/30/2009 17:20 & Pump Sample & 282 & 2.45 & 2.01 & 267 & 15.3 & 0.374 & 0.039 & 0.000 & 0.018 \\
\hline 10/30/2009 18:25 & Pump Sample & 237 & 2.37 & 1.91 & 245 & -8.3 & 0.122 & 0.040 & 0.000 & -0.010 \\
\hline 10/30/2009 19:25 & Pump Sample & 245 & 2.39 & 1.82 & 225 & 20.0 & 0.440 & 0.041 & 0.000 & 0.024 \\
\hline 10/30/2009 20:30 & Pump Sample & 258 & 2.41 & 1.68 & 193 & 65.2 & 0.729 & 0.043 & 0.003 & 0.082 \\
\hline 10/30/2009 21:40 & Pump Sample & 284 & 2.45 & 2.04 & 274 & 10.0 & 0.246 & 0.039 & 0.000 & 0.012 \\
\hline 10/30/2009 23:15 & Pump Sample & 325 & 2.51 & 1.72 & 202 & 122.6 & 0.898 & 0.042 & 0.012 & 0.153 \\
\hline 10/31/2009 1:15 & Pump Sample & 322 & 2.51 & 3.33 & 561 & -238.6 & -1.764 & 0.029 & 0.030 & -0.248 \\
\hline 10/31/2009 3:50 & Pump Sample & 314 & 2.50 & 3.26 & 545 & -231.2 & -1.529 & 0.029 & 0.028 & -0.241 \\
\hline \multicolumn{11}{|l|}{2011 ADVM Data } \\
\hline 4/22/2011 12:00 & Pump Sample & 1250 & 3.10 & 7.18 & --- & --- & --- & --- & --- & --- \\
\hline 4/22/2011 12:17 & EWI & 2160 & 3.33 & 13.27 & --- & --- & --- & --- & --- & --- \\
\hline 4/22/2011 12:20 & Pump Sample & 2570 & 3.41 & 14.39 & --- & --- & --- & --- & --- & --- \\
\hline 4/22/2011 12:40 & Pump Sample & 2520 & 3.40 & 10.60 & --- & --- & --- & --- & --- & --- \\
\hline 4/22/2011 12:58 & EWI & 2830 & 3.45 & 13.03 & --- & --- & --- & --- & --- & --- \\
\hline 4/22/2011 13:00 & Pump Sample & 3000 & 3.48 & 13.22 & --- & --- & --- & --- & --- & --- \\
\hline 4/22/2011 13:35 & Pump Sample & 2260 & 3.35 & 7.94 & --- & --- & --- & --- & --- & --- \\
\hline 4/22/2011 13:41 & Single Vertical & 2020 & 3.31 & 7.68 & --- & --- & --- & --- & --- & --- \\
\hline 4/22/2011 13:45 & Single Vertical & 1980 & 3.30 & 7.23 & --- & --- & --- & --- & --- & --- \\
\hline 4/22/2011 13:48 & Single Vertical & 1870 & 3.27 & 7.23 & --- & --- & --- & --- & --- & --- \\
\hline 4/22/2011 13:54 & Pump Sample & 1780 & 3.25 & 7.05 & --- & --- & --- & --- & --- & --- \\
\hline
\end{tabular}




\begin{tabular}{|c|c|c|c|c|c|c|c|c|c|c|}
\hline \multicolumn{4}{|c|}{ Suspended sediment } & $\begin{array}{l}\text { Acoustic } \\
\text { parameter }\end{array}$ & \multicolumn{6}{|c|}{ Rating information } \\
\hline $\begin{array}{l}\text { Date and time } \\
\text { (CST) }\end{array}$ & $\begin{array}{l}\text { Sample } \\
\text { type }\end{array}$ & $\begin{array}{l}\text { Samp } \\
\text { concentr } \\
\text { (mg/L) }\end{array}$ & $\begin{array}{l}\text { e } \\
\text { ation } \\
\log _{10}\end{array}$ & $\begin{array}{c}\mathrm{SAC} \\
(\mathrm{dB} / \mathrm{m})\end{array}$ & $\begin{array}{l}\text { Predicted SSC } \\
(\mathrm{mg} / \mathrm{L})\end{array}$ & Residual & $\begin{array}{c}\text { Normal } \\
\text { Quantiles }\end{array}$ & Leverage & Cook's D & DFFITS \\
\hline 4/22/2011 13:55 & EWI & 1740 & 3.24 & 7.05 & --- & --- & --- & --- & --- & --- \\
\hline 4/22/2011 14:06 & Point Sample & 1560 & 3.19 & 6.35 & --- & --- & --- & --- & --- & --- \\
\hline 4/22/2011 14:09 & Point Sample & 1510 & 3.18 & 6.37 & --- & --- & --- & --- & --- & --- \\
\hline 4/22/2011 14:12 & Point Sample & 1500 & 3.18 & 6.37 & --- & --- & --- & --- & --- & --- \\
\hline 4/22/2011 14:13 & Point Sample & 1430 & 3.16 & 6.37 & --- & --- & --- & --- & --- & --- \\
\hline 4/22/2011 14:18 & Point Sample & 1390 & 3.14 & 5.81 & --- & --- & --- & --- & --- & --- \\
\hline 4/22/2011 14:22 & Point Sample & 1390 & 3.14 & 5.67 & --- & --- & --- & --- & --- & --- \\
\hline 4/22/2011 14:25 & Point Sample & 1320 & 3.12 & 5.72 & --- & --- & --- & --- & --- & --- \\
\hline 4/22/2011 14:33 & Single Vertical & 1270 & 3.10 & 5.09 & --- & --- & --- & --- & --- & --- \\
\hline 4/22/2011 14:35 & Single Vertical & 1230 & 3.09 & 5.22 & --- & --- & --- & --- & --- & --- \\
\hline 4/22/2011 14:47 & Point Sample & 1100 & 3.04 & 4.79 & --- & --- & --- & --- & --- & --- \\
\hline 4/22/2011 14:49 & Point Sample & 1140 & 3.06 & 4.62 & --- & --- & --- & --- & --- & --- \\
\hline 4/22/2011 14:56 & Single Vertical & 1080 & 3.03 & 4.67 & --- & --- & --- & -- & --- & --- \\
\hline 4/22/2011 14:59 & Single Vertical & 1070 & 3.03 & 4.46 & --- & --- & --- & --- & --- & --- \\
\hline 4/22/2011 15:01 & Point Sample & 1030 & 3.01 & 4.46 & --- & --- & --- & --- & --- & --- \\
\hline 4/22/2011 15:04 & Point Sample & 1010 & 3.00 & 4.21 & --- & --- & --- & --- & --- & --- \\
\hline 4/22/2011 15:07 & Single Vertical & 1020 & 3.01 & 4.21 & --- & --- & --- & --- & --- & --- \\
\hline 4/22/2011 15:10 & Single Vertical & 970 & 2.99 & 4.30 & --- & --- & --- & -- & --- & --- \\
\hline 4/22/2011 15:13 & Point Sample & 979 & 2.99 & 4.30 & --- & --- & --- & -- & --- & --- \\
\hline 4/22/2011 15:20 & Point Sample & 995 & 3.00 & 4.02 & --- & --- & --- & -- & --- & --- \\
\hline 4/22/2011 15:23 & Single Vertical & 889 & 2.95 & 4.02 & --- & --- & --- & -- & --- & --- \\
\hline 4/22/2011 15:26 & Single Vertical & 908 & 2.96 & 4.26 & --- & --- & --- & -- & --- & --- \\
\hline 4/22/2011 15:42 & Point Sample & 822 & 2.91 & 3.80 & --- & --- & --- & -- & --- & --- \\
\hline 4/22/2011 15:45 & Point Sample & 812 & 2.91 & 3.54 & --- & --- & --- & -- & --- & --- \\
\hline 4/22/2011 15:49 & Single Vertical & 744 & 2.87 & 3.36 & --- & --- & -- & -- & --- & --- \\
\hline 4/22/2011 15:56 & Single Vertical & 791 & 2.90 & 3.26 & --- & --- & --- & --- & --- & --- \\
\hline 4/22/2011 15:59 & Point Sample & 756 & 2.88 & 3.45 & --- & --- & --- & -- & --- & --- \\
\hline 4/22/2011 16:02 & Point Sample & 734 & 2.87 & 3.45 & --- & --- & --- & -- & --- & --- \\
\hline
\end{tabular}




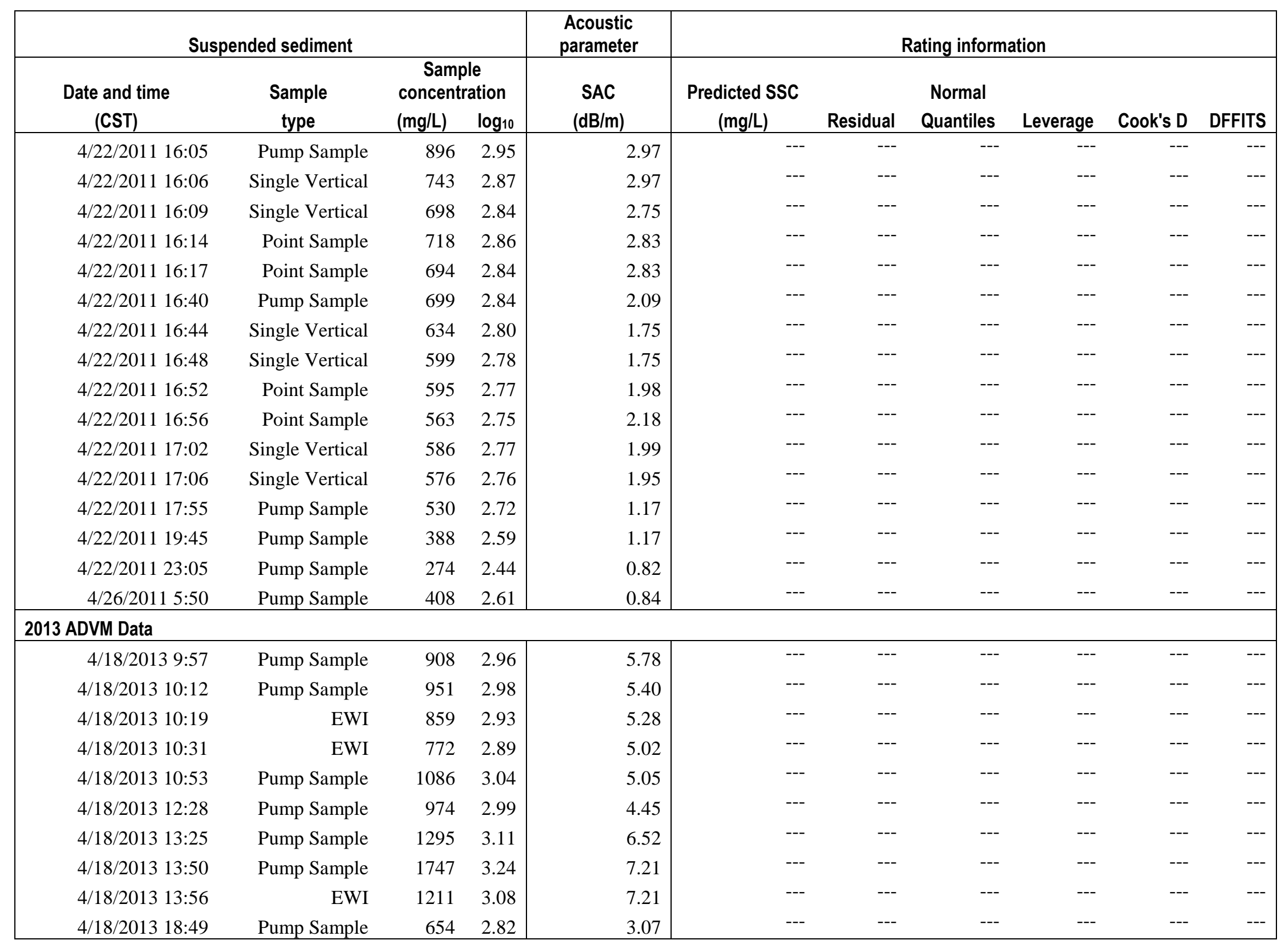




\begin{tabular}{|c|c|c|c|c|c|c|c|c|c|c|}
\hline \multicolumn{4}{|c|}{ Suspended sediment } & \multirow{2}{*}{$\begin{array}{c}\begin{array}{c}\text { Acoustic } \\
\text { parameter }\end{array} \\
\text { SAC } \\
(\mathrm{dB} / \mathrm{m}) \\
\end{array}$} & \multicolumn{6}{|c|}{ Rating information } \\
\hline $\begin{array}{l}\text { Date and time } \\
\text { (CST) }\end{array}$ & $\begin{array}{c}\text { Sample } \\
\text { type }\end{array}$ & $\begin{array}{r}\text { Samp } \\
\text { concent } \\
(\mathrm{mg} / \mathrm{L})\end{array}$ & $\begin{array}{l}\text { le } \\
\text { ation } \\
\log _{10} \\
\end{array}$ & & $\begin{array}{c}\text { Predicted SSC } \\
(\mathrm{mg} / \mathrm{L})\end{array}$ & Residual & $\begin{array}{c}\text { Normal } \\
\text { Quantiles }\end{array}$ & Leverage & Cook's D & DFFITS \\
\hline \multicolumn{11}{|l|}{2015 ADVM Data } \\
\hline 6/7/2015 17:26 & Pump Sample & 268 & 2.43 & 4.65 & 626 & -357.6 & -1.546 & 0.039 & 0.034 & -0.265 \\
\hline 6/7/2015 17:56 & Pump Sample & 481 & 2.68 & 6.23 & 863 & -382.3 & -1.997 & 0.040 & 0.039 & -0.285 \\
\hline 6/7/2015 18:27 & Pump Sample & 3320 & 3.52 & 23.95 & 3536 & -215.7 & -0.668 & 0.551 & 0.795 & -1.269 \\
\hline 6/7/2015 19:06 & Pump Sample & 2840 & 3.45 & 18.25 & 2675 & 164.7 & 0.794 & 0.284 & 0.094 & 0.429 \\
\hline 6/8/2015 8:38 & Pump Sample & 354 & 2.55 & 2.06 & 235 & 119.0 & 0.553 & 0.055 & 0.005 & 0.102 \\
\hline 6/8/2015 9:24 & Pump Sample & 125 & 2.10 & 2.35 & 278 & -152.8 & -0.445 & 0.052 & 0.008 & -0.128 \\
\hline 6/8/2015 9:47 & Pump Sample & 118 & 2.07 & 2.17 & 252 & -133.6 & -0.341 & 0.054 & 0.007 & -0.114 \\
\hline 6/8/2015 20:16 & Pump Sample & 336 & 2.53 & 3.49 & 451 & -114.7 & -0.242 & 0.044 & 0.004 & -0.087 \\
\hline 6/8/2015 20:20 & Pump Sample & 313 & 2.50 & 4.25 & 565 & -252.2 & -0.794 & 0.040 & 0.017 & -0.186 \\
\hline 6/17/2015 13:31 & Pump Sample & 171 & 2.23 & 3.50 & 452 & -281.0 & -1.092 & 0.044 & 0.024 & -0.217 \\
\hline 6/17/2015 13:57 & Pump Sample & 1130 & 3.05 & 9.04 & 1286 & -156.4 & -0.553 & 0.058 & 0.010 & -0.140 \\
\hline 6/17/2015 14:31 & Pump Sample & 1150 & 3.06 & 8.58 & 1218 & -68.4 & -0.144 & 0.054 & 0.002 & -0.058 \\
\hline 6/17/2015 15:41 & Pump Sample & 932 & 2.97 & 5.72 & 786 & 145.6 & 0.668 & 0.039 & 0.006 & 0.104 \\
\hline 6/17/2015 23:51 & Pump Sample & 259 & 2.41 & 2.38 & 283 & -24.3 & 0.048 & 0.052 & 0.000 & -0.020 \\
\hline 7/8/2015 20:33 & Pump sample & 85 & 1.93 & 3.30 & 422 & -336.6 & -1.286 & 0.045 & 0.035 & -0.267 \\
\hline 7/8/2015 20:44 & Pump sample & 117 & 2.07 & 3.00 & 377 & -260.0 & -0.932 & 0.047 & 0.022 & -0.208 \\
\hline 7/8/2015 20:56 & Pump Sample & 360 & 2.56 & 3.27 & 418 & -57.7 & -0.048 & 0.045 & 0.001 & -0.044 \\
\hline 7/8/2015 21:07 & Pump Sample & 1380 & 3.14 & 7.26 & 1019 & 361.3 & 1.092 & 0.044 & 0.039 & 0.284 \\
\hline 7/8/2015 21:19 & Pump Sample & 1250 & 3.10 & 6.97 & 975 & 274.8 & 0.932 & 0.042 & 0.022 & 0.208 \\
\hline 7/8/2015 21:31 & Pump Sample & 1300 & 3.11 & 5.47 & 748 & 551.5 & 1.546 & 0.038 & 0.079 & 0.426 \\
\hline 7/8/2015 21:53 & Pump Sample & 1200 & 3.08 & 5.19 & 706 & 494.1 & 1.286 & 0.039 & 0.064 & 0.375 \\
\hline 7/8/2015 22:28 & Pump Sample & 1060 & 3.03 & 3.57 & 463 & 597.5 & 1.997 & 0.043 & 0.106 & 0.501 \\
\hline 7/9/2015 5:06 & Pump Sample & 255 & 2.41 & 1.41 & 136 & 118.8 & 0.445 & 0.062 & 0.006 & 0.110 \\
\hline 7/9/2015 7:28 & Pump Sample & 116 & 2.06 & 1.35 & 128 & -11.5 & 0.242 & 0.063 & 0.000 & -0.011 \\
\hline 7/9/2015 7:35 & EWI & 103 & 2.01 & 1.29 & 119 & -16.1 & 0.144 & 0.063 & 0.000 & -0.015 \\
\hline 7/9/2015 7:41 & Pump Sample & 109 & 2.04 & 1.27 & 115 & -6.4 & 0.341 & 0.064 & 0.000 & -0.006 \\
\hline
\end{tabular}




\begin{tabular}{|c|c|c|c|c|c|c|c|c|c|c|}
\hline \multicolumn{4}{|c|}{ Suspended sediment } & $\begin{array}{c}\text { Acoustic } \\
\text { parameter }\end{array}$ & \multicolumn{6}{|c|}{ Rating information } \\
\hline $\begin{array}{c}\text { Date and time } \\
\text { (CST) }\end{array}$ & $\begin{array}{c}\text { Sample } \\
\text { type }\end{array}$ & $\begin{array}{r}\text { Sam } \\
\text { concent } \\
(\mathrm{mg} / \mathrm{L})\end{array}$ & $\begin{array}{l}e \\
\text { ation } \\
\log _{10} \\
\end{array}$ & $\begin{array}{c}\mathrm{SAC} \\
(\mathrm{dB} / \mathrm{m})\end{array}$ & $\begin{array}{c}\text { Predicted SSC } \\
(\mathrm{mg} / \mathrm{L})\end{array}$ & Residual & $\begin{array}{c}\text { Normal } \\
\text { Quantiles }\end{array}$ & Leverage & Cook's D & DFFITS \\
\hline \multicolumn{11}{|l|}{2011 ADCP Data } \\
\hline 4/22/2011 13:35 & Pump Sample & 2260 & 3.35 & 5.36 & --- & --- & --- & --- & --- & --- \\
\hline 4/22/2011 13:41 & Single Vertical & 2020 & 3.31 & 4.44 & --- & --- & --- & --- & --- & --- \\
\hline $4 / 22 / 2011$ 13:45 & Single Vertical & 1980 & 3.30 & 4.36 & --- & --- & --- & --- & --- & --- \\
\hline 4/22/2011 13:48 & Single Vertical & 1870 & 3.27 & 4.32 & --- & --- & --- & --- & --- & --- \\
\hline 4/22/2011 13:54 & Pump Sample & 1780 & 3.25 & 4.21 & --- & --- & --- & --- & --- & --- \\
\hline 4/22/2011 13:55 & EWI & 1740 & 3.24 & 4.21 & --- & --- & --- & --- & --- & --- \\
\hline 4/22/2011 14:06 & Point Sample & 1560 & 3.19 & 3.98 & --- & --- & --- & --- & --- & --- \\
\hline 4/22/2011 14:09 & Point Sample & 1510 & 3.18 & 3.77 & --- & --- & --- & --- & --- & --- \\
\hline 4/22/2011 14:12 & Point Sample & 1500 & 3.18 & 3.45 & --- & --- & --- & --- & --- & --- \\
\hline $4 / 22 / 201114: 13$ & Point Sample & 1430 & 3.16 & 3.52 & --- & --- & --- & --- & --- & --- \\
\hline $4 / 22 / 2011$ 14:18 & Point Sample & 1390 & 3.14 & 3.01 & --- & --- & --- & --- & --- & --- \\
\hline 4/22/2011 14:22 & Point Sample & 1390 & 3.14 & 2.98 & --- & --- & --- & --- & --- & --- \\
\hline 4/22/2011 14:25 & Point Sample & 1320 & 3.12 & 2.68 & --- & --- & --- & --- & --- & --- \\
\hline 4/22/2011 14:33 & Single Vertical & 1270 & 3.10 & 3.11 & --- & --- & --- & --- & --- & --- \\
\hline 4/22/2011 14:35 & Single Vertical & 1230 & 3.09 & 2.60 & --- & --- & --- & --- & --- & --- \\
\hline 4/22/2011 14:47 & Point Sample & 1100 & 3.04 & 2.15 & --- & --- & --- & --- & --- & --- \\
\hline $4 / 22 / 2011$ 14:49 & Point Sample & 1140 & 3.06 & 1.81 & --- & --- & --- & --- & --- & --- \\
\hline 4/22/2011 14:56 & Single Vertical & 1080 & 3.03 & 2.58 & --- & --- & --- & --- & --- & --- \\
\hline 4/22/2011 14:59 & Single Vertical & 1070 & 3.03 & 3.03 & --- & --- & --- & --- & --- & --- \\
\hline 4/22/2011 15:01 & Point Sample & 1030 & 3.01 & 2.49 & --- & --- & --- & --- & --- & --- \\
\hline 4/22/2011 15:04 & Point Sample & 1010 & 3.00 & 2.48 & --- & --- & --- & --- & --- & --- \\
\hline $4 / 22 / 2011$ 15:07 & Single Vertical & 1020 & 3.01 & 2.38 & --- & --- & --- & --- & --- & --- \\
\hline 4/22/2011 15:10 & Single Vertical & 970 & 2.99 & 2.16 & --- & --- & --- & --- & --- & --- \\
\hline 4/22/2011 15:13 & Point Sample & 979 & 2.99 & 2.40 & --- & --- & --- & --- & --- & --- \\
\hline $4 / 22 / 2011$ 15:20 & Point Sample & 995 & 3.00 & 2.55 & --- & --- & --- & --- & --- & --- \\
\hline 4/22/2011 15:23 & Single Vertical & 889 & 2.95 & 2.18 & --- & -- & --- & --- & --- & --- \\
\hline 4/22/2011 15:26 & Single Vertical & 908 & 2.96 & 2.07 & --- & --- & --- & --- & --- & --- \\
\hline
\end{tabular}




\begin{tabular}{|c|c|c|c|c|c|c|c|c|c|c|}
\hline \multicolumn{4}{|c|}{ Suspended sediment } & \multirow{2}{*}{$\begin{array}{c}\text { Acoustic } \\
\text { parameter } \\
\text { SAC } \\
(\mathrm{dB} / \mathrm{m}) \\
\end{array}$} & \multicolumn{6}{|c|}{ Rating information } \\
\hline $\begin{array}{c}\text { Date and time } \\
\text { (CST) }\end{array}$ & $\begin{array}{c}\text { Sample } \\
\text { type }\end{array}$ & $\begin{array}{l}\text { Samp } \\
\text { concent } \\
\text { (mg/L) }\end{array}$ & $\begin{array}{l}\text { le } \\
\text { ation } \\
\log _{10} \\
\end{array}$ & & $\begin{array}{c}\text { Predicted SSC } \\
(\mathrm{mg} / \mathrm{L})\end{array}$ & Residual & $\begin{array}{c}\text { Normal } \\
\text { Quantiles }\end{array}$ & Leverage & Cook's D & DFFITS \\
\hline 4/22/2011 15:42 & Point Sample & 822 & 2.91 & 1.80 & --- & --- & --- & --- & --- & --- \\
\hline $4 / 22 / 2011$ 15:45 & Point Sample & 812 & 2.91 & 1.62 & --- & --- & --- & --- & --- & --- \\
\hline 4/22/2011 15:49 & Single Vertical & 744 & 2.87 & 1.49 & --- & --- & --- & --- & --- & --- \\
\hline $4 / 22 / 2011$ 15:56 & Single Vertical & 791 & 2.90 & 1.32 & --- & --- & --- & --- & --- & --- \\
\hline 4/22/2011 15:59 & Point Sample & 756 & 2.88 & 1.21 & --- & --- & --- & --- & --- & --- \\
\hline 4/22/2011 16:02 & Point Sample & 734 & 2.87 & 1.08 & --- & --- & --- & --- & --- & --- \\
\hline 4/22/2011 16:05 & Pump Sample & 896 & 2.95 & 1.28 & --- & --- & --- & --- & --- & --- \\
\hline 4/22/2011 16:06 & Single Vertical & 743 & 2.87 & 1.36 & -- & --- & --- & --- & --- & --- \\
\hline 4/22/2011 16:09 & Single Vertical & 698 & 2.84 & 1.17 & --- & --- & --- & --- & --- & --- \\
\hline 4/22/2011 16:14 & Point Sample & 718 & 2.86 & 1.03 & --- & --- & --- & --- & --- & --- \\
\hline 4/22/2011 16:40 & Pump Sample & 699 & 2.84 & 0.96 & --- & --- & --- & --- & --- & --- \\
\hline $4 / 22 / 2011$ 16:44 & Single Vertical & 634 & 2.80 & 1.00 & --- & --- & --- & --- & --- & --- \\
\hline 4/22/2011 16:48 & Single Vertical & 599 & 2.78 & 0.81 & --- & --- & --- & --- & --- & --- \\
\hline 4/22/2011 16:52 & Point Sample & 595 & 2.77 & 1.35 & --- & --- & --- & --- & --- & --- \\
\hline 4/22/2011 16:56 & Point Sample & 563 & 2.75 & 0.68 & --- & --- & --- & --- & --- & --- \\
\hline 4/22/2011 17:02 & Single Vertical & 586 & 2.77 & 0.90 & --- & --- & --- & --- & --- & --- \\
\hline 4/22/2011 17:06 & Single Vertical & 576 & 2.76 & 0.85 & --- & --- & --- & --- & --- & --- \\
\hline
\end{tabular}




\section{Appendix 4. Mean Sediment Corrected Backscatter Data}

[MeanSCB, average sediment-corrected backscatter; mg/L, milligrams per liter; SSC, suspended-sediment concentration; dB, decibels; log 10 , base-10 logarithmic transform; EWI, equal width increment; DFFITS, difference in fit statistic; CST, Central (U.S.) standard time; ---, not applicable]

\begin{tabular}{|c|c|c|c|c|c|c|c|c|c|c|c|}
\hline \multicolumn{4}{|c|}{ Suspended sediment } & \multirow{2}{*}{$\begin{array}{l}\text { Acoustic } \\
\text { parameter } \\
\text { MeanSCB } \\
\text { (dB) }\end{array}$} & \multicolumn{7}{|c|}{ Rating information } \\
\hline $\begin{array}{l}\text { Date and time } \\
\text { (CST) }\end{array}$ & $\begin{array}{c}\text { Sample } \\
\text { type }\end{array}$ & \multicolumn{2}{|c|}{$\begin{array}{c}\text { Sample } \\
\text { concentration }\end{array}$} & & \multicolumn{2}{|c|}{ Predicted SSC } & $\begin{array}{l}\text { Residual } \\
\log _{10}\end{array}$ & $\begin{array}{c}\text { Normal } \\
\text { Quantiles }\end{array}$ & Leverage & Cook's D & DFFITS \\
\hline \multicolumn{12}{|l|}{2009 ADVM Data } \\
\hline $10 / 23 / 20095: 50$ & Pump sample & 1150 & 3.06 & 91.2 & --- & --- & --- & --- & --- & --- & --- \\
\hline 10/23/2009 2:10 & Pump sample & 2070 & 3.32 & 94.3 & --- & --- & --- & --- & --- & --- & --- \\
\hline 10/23/2009 2:25 & Pump sample & 2360 & 3.37 & 93.1 & --- & --- & --- & --- & --- & --- & --- \\
\hline 10/23/2009 2:40 & Pump sample & 2910 & 3.46 & 92.7 & --- & --- & --- & --- & --- & --- & --- \\
\hline 10/23/2009 3:00 & Pump sample & 2380 & 3.38 & 94.2 & --- & --- & --- & --- & --- & --- & --- \\
\hline 10/23/2009 3:30 & Pump sample & 1840 & 3.26 & 94.3 & --- & --- & --- & --- & --- & --- & --- \\
\hline 10/23/2009 4:15 & Pump sample & 1200 & 3.08 & 93.3 & --- & --- & --- & --- & --- & --- & --- \\
\hline 10/23/2009 5:30 & Pump sample & 692 & 2.84 & 91.4 & --- & --- & --- & --- & --- & --- & --- \\
\hline 10/23/2009 8:35 & Pump sample & 388 & 2.59 & 85.7 & --- & --- & --- & --- & --- & --- & --- \\
\hline 10/23/2009 9:44 & EWI & 316 & 2.50 & 86.4 & --- & --- & --- & --- & --- & --- & --- \\
\hline 10/23/2009 9:45 & Pump sample & 332 & 2.52 & 86.4 & --- & --- & --- & --- & --- & --- & --- \\
\hline 10/23/2009 10:00 & Pump sample & 301 & 2.48 & 86.1 & --- & --- & --- & --- & --- & --- & --- \\
\hline 10/23/2009 11:05 & Pump sample & 304 & 2.48 & 85.7 & --- & --- & --- & --- & --- & --- & --- \\
\hline 10/23/2009 11:11 & EWI & 300 & 2.48 & 86.7 & --- & --- & --- & --- & --- & --- & --- \\
\hline $10 / 23 / 200911: 25$ & Pump sample & 304 & 2.48 & 85.8 & --- & --- & --- & --- & --- & --- & --- \\
\hline 10/23/2009 12:40 & Pump sample & 322 & 2.51 & 86.4 & --- & --- & --- & --- & --- & --- & --- \\
\hline 10/23/2009 14:05 & Pump sample & 294 & 2.47 & 88.5 & --- & --- & --- & --- & --- & --- & --- \\
\hline 10/23/2009 15:50 & Pump sample & 322 & 2.51 & 89.1 & --- & --- & --- & --- & --- & --- & --- \\
\hline 10/29/2009 21:15 & Pump sample & 1480 & 3.17 & 94.5 & --- & --- & --- & --- & --- & --- & --- \\
\hline 10/29/2009 21:25 & Pump sample & 1770 & 3.25 & 94.7 & --- & --- & --- & --- & --- & --- & --- \\
\hline 10/29/2009 21:35 & Pump sample & 2260 & 3.35 & 97.7 & --- & --- & --- & --- & --- & --- & --- \\
\hline 10/29/2009 21:45 & Pump sample & 3010 & 3.48 & 99.6 & --- & --- & --- & --- & --- & --- & --- \\
\hline 10/29/2009 22:00 & Pump sample & 2370 & 3.37 & 97.8 & --- & --- & --- & --- & --- & --- & --- \\
\hline 10/29/2009 22:25 & Pump sample & 1640 & 3.21 & 97.6 & --- & --- & --- & -- & --- & --- & --- \\
\hline
\end{tabular}




\begin{tabular}{|c|c|c|c|c|c|c|c|c|c|c|c|}
\hline \multicolumn{4}{|c|}{ Suspended sediment } & $\begin{array}{l}\text { Acoustic } \\
\text { parameter }\end{array}$ & \multicolumn{7}{|c|}{ Rating information } \\
\hline \multirow{2}{*}{$\begin{array}{l}\text { Date and time } \\
\text { (CST) }\end{array}$} & \multirow{2}{*}{$\begin{array}{l}\text { Sample } \\
\text { type }\end{array}$} & \multicolumn{2}{|c|}{$\begin{array}{c}\text { Sample } \\
\text { concentration }\end{array}$} & \multirow{2}{*}{$\begin{array}{l}\text { MeanSCB } \\
(\mathrm{dB})\end{array}$} & \multicolumn{2}{|c|}{ Predicted SSC } & \multirow{2}{*}{$\begin{array}{l}\text { Residual } \\
\log _{10}\end{array}$} & \multirow{2}{*}{$\begin{array}{c}\text { Normal } \\
\text { Quantiles }\end{array}$} & \multirow[b]{2}{*}{ Leverage } & \multirow[b]{2}{*}{ Cook's D } & \multirow[b]{2}{*}{ DFFITS } \\
\hline & & (mg/L) & $\log _{10}$ & & $(\mathrm{mg} / \mathrm{L})$ & $\log _{10}$ & & & & & \\
\hline 10/29/2009 22:45 & Pump sample & 1160 & 3.06 & 95.4 & --- & --- & --- & --- & --- & --- & --- \\
\hline 10/29/2009 23:25 & Pump sample & 865 & 2.94 & 94.2 & --- & --- & --- & --- & --- & --- & --- \\
\hline 10/30/2009 1:20 & EWI & 488 & 2.69 & 89.7 & --- & --- & --- & --- & --- & --- & --- \\
\hline 10/30/2009 2:30 & Pump sample & 415 & 2.62 & 87.1 & --- & --- & --- & --- & --- & -- & --- \\
\hline 10/30/2009 3:40 & Pump sample & 340 & 2.53 & 86.0 & --- & --- & --- & --- & --- & --- & --- \\
\hline 10/30/2009 9:30 & Pump sample & 294 & 2.47 & 85.5 & --- & --- & --- & --- & --- & -- & --- \\
\hline 10/30/2009 11:20 & Pump sample & 356 & 2.55 & 85.9 & --- & --- & --- & --- & --- & --- & --- \\
\hline 10/30/2009 11:55 & Pump sample & 441 & 2.64 & 87.4 & --- & --- & --- & --- & --- & -- & --- \\
\hline 10/30/2009 12:30 & Pump sample & 481 & 2.68 & 89.5 & --- & --- & --- & --- & --- & -- & -- \\
\hline 10/30/2009 17:20 & Pump sample & 282 & 2.45 & 83.9 & --- & --- & --- & --- & --- & -- & --- \\
\hline 10/30/2009 18:25 & Pump sample & 237 & 2.37 & 83.4 & --- & --- & --- & --- & --- & -- & -- \\
\hline 10/30/2009 19:25 & Pump sample & 245 & 2.39 & 85.4 & -- & --- & --- & --- & --- & --- & --- \\
\hline 10/30/2009 20:30 & Pump sample & 258 & 2.41 & 86.5 & --- & --- & --- & --- & --- & --- & --- \\
\hline 10/30/2009 21:40 & Pump sample & 284 & 2.45 & 89.0 & --- & --- & --- & --- & --- & -- & --- \\
\hline 10/30/2009 23:15 & Pump sample & 325 & 2.51 & 89.6 & --- & --- & --- & --- & --- & -- & -- \\
\hline 10/31/2009 1:15 & Pump sample & 322 & 2.51 & 92.4 & --- & --- & --- & --- & --- & -- & --- \\
\hline 10/31/2009 3:50 & Pump sample & 314 & 2.50 & 91.5 & --- & --- & --- & --- & --- & --- & -- \\
\hline \multicolumn{12}{|l|}{2011 ADVM Data } \\
\hline 4/22/2011 12:00 & Pump sample & 1250 & 3.10 & 87.4 & 1366 & 3.13 & -0.037 & -1.383 & 0.023 & 0.010 & -0.139 \\
\hline 4/22/2011 12:17 & EWI & 2160 & 3.33 & 90.5 & 2113 & 3.32 & 0.011 & 0.372 & 0.053 & 0.002 & 0.067 \\
\hline 4/22/2011 12:20 & Pump sample & 2570 & 3.41 & 91.8 & 2512 & 3.40 & 0.012 & 0.421 & 0.073 & 0.003 & 0.082 \\
\hline 4/22/2011 12:40 & Pump sample & 2520 & 3.40 & 91.4 & 2368 & 3.37 & 0.029 & 0.870 & 0.065 & 0.019 & 0.192 \\
\hline 4/22/2011 12:58 & EWI & 2830 & 3.45 & 92.4 & 2744 & 3.44 & 0.015 & 0.522 & 0.084 & 0.007 & 0.116 \\
\hline 4/22/2011 13:00 & Pump sample & 3000 & 3.48 & 92.9 & 2951 & 3.47 & 0.009 & 0.183 & 0.094 & 0.003 & 0.074 \\
\hline 4/22/2011 13:35 & Pump sample & 2260 & 3.35 & 89.9 & 1934 & 3.28 & 0.070 & 1.896 & 0.045 & 0.070 & 0.383 \\
\hline 4/22/2011 13:41 & Single Vertical & 2020 & 3.31 & 89.6 & 1849 & 3.27 & 0.040 & 1.177 & 0.041 & 0.021 & 0.207 \\
\hline 4/22/2011 13:45 & Single Vertical & 1980 & 3.30 & 89.5 & 1826 & 3.26 & 0.037 & 1.012 & 0.040 & 0.018 & 0.187 \\
\hline 4/22/2011 13:48 & Single Vertical & 1870 & 3.27 & 89.5 & 1826 & 3.26 & 0.012 & 0.471 & 0.040 & 0.002 & 0.061 \\
\hline
\end{tabular}




\begin{tabular}{|c|c|c|c|c|c|c|c|c|c|c|c|}
\hline \multicolumn{4}{|c|}{ Suspended sediment } & \multirow{3}{*}{$\begin{array}{c}\text { Acoustic } \\
\text { parameter } \\
\text { MeanSCB } \\
\text { (dB) }\end{array}$} & \multicolumn{7}{|c|}{ Rating information } \\
\hline \multirow{2}{*}{$\begin{array}{l}\text { Date and time } \\
\text { (CST) }\end{array}$} & \multirow{2}{*}{$\begin{array}{c}\text { Sample } \\
\text { type }\end{array}$} & \multicolumn{2}{|c|}{$\begin{array}{c}\text { Sample } \\
\text { concentration }\end{array}$} & & \multicolumn{2}{|c|}{ Predicted SSC } & \multirow{2}{*}{$\begin{array}{c}\text { Residual } \\
\log _{10} \\
\end{array}$} & \multirow{2}{*}{$\begin{array}{c}\text { Normal } \\
\text { Quantiles }\end{array}$} & \multirow[b]{2}{*}{ Leverage } & \multirow[b]{2}{*}{ Cook's D } & \multirow[b]{2}{*}{ DFFITS } \\
\hline & & (mg/L) & $\log _{10}$ & & (mg/L) & $\log _{10}$ & & & & & \\
\hline 4/22/2011 13:54 & Pump sample & 1780 & 3.25 & 89.8 & 1897 & 3.28 & -0.026 & -0.870 & 0.043 & 0.009 & -0.136 \\
\hline 4/22/2011 13:55 & EWI & 1740 & 3.24 & 89.8 & 1897 & 3.28 & -0.036 & -1.177 & 0.043 & 0.018 & -0.189 \\
\hline 4/22/2011 14:06 & Point Sample & 1560 & 3.19 & 88.8 & 1658 & 3.22 & -0.025 & -0.686 & 0.033 & 0.006 & -0.112 \\
\hline 4/22/2011 14:09 & Point Sample & 1510 & 3.18 & 88.7 & 1638 & 3.21 & -0.033 & -1.012 & 0.033 & 0.012 & -0.151 \\
\hline 4/22/2011 14:12 & Point Sample & 1500 & 3.18 & 88.7 & 1638 & 3.21 & -0.036 & -1.273 & 0.033 & 0.014 & -0.165 \\
\hline 4/22/2011 14:13 & Point Sample & 1430 & 3.16 & 88.7 & 1638 & 3.21 & -0.057 & -1.674 & 0.033 & 0.034 & -0.262 \\
\hline 4/22/2011 14:18 & Point Sample & 1390 & 3.14 & 88.0 & 1481 & 3.17 & -0.026 & -0.806 & 0.027 & 0.006 & -0.104 \\
\hline 4/22/2011 14:22 & Point Sample & 1390 & 3.14 & 88.0 & 1475 & 3.17 & -0.024 & -0.630 & 0.027 & 0.005 & -0.096 \\
\hline 4/22/2011 14:25 & Point Sample & 1320 & 3.12 & 88.1 & 1510 & 3.18 & -0.056 & -1.512 & 0.028 & 0.028 & -0.238 \\
\hline 4/22/2011 14:33 & Single Vertical & 1270 & 3.10 & 86.8 & 1249 & 3.09 & 0.009 & 0.229 & 0.021 & 0.001 & 0.032 \\
\hline 4/22/2011 14:35 & Single Vertical & 1230 & 3.09 & 87.2 & 1324 & 3.12 & -0.030 & -0.939 & 0.022 & 0.006 & -0.111 \\
\hline 4/22/2011 14:47 & Point Sample & 1100 & 3.04 & 86.2 & 1160 & 3.06 & -0.021 & -0.522 & 0.019 & 0.003 & -0.072 \\
\hline 4/22/2011 14:49 & Point Sample & 1140 & 3.06 & 86.0 & 1128 & 3.05 & 0.006 & 0.091 & 0.019 & 0.000 & 0.021 \\
\hline 4/22/2011 14:56 & Single Vertical & 1080 & 3.03 & 85.9 & 1108 & 3.04 & -0.009 & -0.276 & 0.018 & 0.000 & -0.031 \\
\hline 4/22/2011 14:59 & Single Vertical & 1070 & 3.03 & 85.6 & 1059 & 3.02 & 0.006 & 0.137 & 0.018 & 0.000 & 0.021 \\
\hline 4/22/2011 15:01 & Point Sample & 1030 & 3.01 & 85.6 & 1059 & 3.02 & -0.010 & -0.323 & 0.018 & 0.001 & -0.034 \\
\hline 4/22/2011 15:04 & Point Sample & 1010 & 3.00 & 85.0 & 971 & 2.99 & 0.019 & 0.575 & 0.018 & 0.002 & 0.063 \\
\hline 4/22/2011 15:07 & Single Vertical & 1020 & 3.01 & 85.0 & 971 & 2.99 & 0.023 & 0.630 & 0.018 & 0.003 & 0.077 \\
\hline 4/22/2011 15:10 & Single Vertical & 970 & 2.99 & 85.0 & 976 & 2.99 & -0.001 & -0.091 & 0.018 & 0.000 & -0.003 \\
\hline 4/22/2011 15:13 & Point Sample & 979 & 2.99 & 85.0 & 976 & 2.99 & 0.003 & 0.000 & 0.018 & 0.000 & 0.011 \\
\hline 4/22/2011 15:20 & Point Sample & 995 & 3.00 & 84.4 & 901 & 2.95 & 0.045 & 1.273 & 0.020 & 0.012 & 0.156 \\
\hline 4/22/2011 15:23 & Single Vertical & 889 & 2.95 & 84.4 & 901 & 2.95 & -0.004 & -0.137 & 0.020 & 0.000 & -0.013 \\
\hline 4/22/2011 15:26 & Single Vertical & 908 & 2.96 & 84.6 & 931 & 2.97 & -0.009 & -0.229 & 0.019 & 0.000 & -0.031 \\
\hline 4/22/2011 15:42 & Point Sample & 822 & 2.91 & 83.8 & 826 & 2.92 & 0.000 & -0.045 & 0.022 & 0.000 & -0.001 \\
\hline 4/22/2011 15:45 & Point Sample & 812 & 2.91 & 83.6 & 804 & 2.90 & 0.006 & 0.045 & 0.023 & 0.000 & 0.022 \\
\hline 4/22/2011 15:49 & Single Vertical & 744 & 2.87 & 83.4 & 778 & 2.89 & -0.017 & -0.471 & 0.024 & 0.002 & -0.067 \\
\hline 4/22/2011 15:56 & Single Vertical & 791 & 2.90 & 83.1 & 747 & 2.87 & 0.027 & 0.806 & 0.026 & 0.006 & 0.107 \\
\hline 4/22/2011 15:59 & Point Sample & 756 & 2.88 & 83.4 & 782 & 2.89 & -0.013 & -0.421 & 0.024 & 0.001 & -0.048 \\
\hline
\end{tabular}




\begin{tabular}{|c|c|c|c|c|c|c|c|c|c|c|c|}
\hline \multicolumn{4}{|c|}{ Suspended sediment } & $\begin{array}{l}\text { Acoustic } \\
\text { parameter }\end{array}$ & \multicolumn{7}{|c|}{ Rating information } \\
\hline \multirow{2}{*}{$\begin{array}{l}\text { Date and time } \\
\text { (CST) }\end{array}$} & \multirow{2}{*}{$\begin{array}{c}\text { Sample } \\
\text { type }\end{array}$} & \multicolumn{2}{|c|}{$\begin{array}{c}\text { Sample } \\
\text { concentration }\end{array}$} & \multirow{2}{*}{$\begin{array}{c}\text { MeanSCB } \\
(\mathrm{dB})\end{array}$} & \multicolumn{2}{|c|}{ Predicted SSC } & \multirow{2}{*}{$\begin{array}{c}\text { Residual } \\
\log _{10} \\
\end{array}$} & \multirow{2}{*}{$\begin{array}{c}\text { Normal } \\
\text { Quantiles }\end{array}$} & \multirow[b]{2}{*}{ Leverage } & \multirow[b]{2}{*}{ Cook's D } & \multirow[b]{2}{*}{ DFFITS } \\
\hline & & (mg/L) & $\log _{10}$ & & (mg/L) & $\log _{10}$ & & & & & \\
\hline 4/22/2011 16:02 & Point Sample & 734 & 2.87 & 83.4 & 782 & 2.89 & -0.025 & -0.745 & 0.024 & 0.005 & -0.097 \\
\hline 4/22/2011 16:05 & Pump sample & 896 & 2.95 & 82.7 & 706 & 2.85 & 0.105 & 2.295 & 0.029 & 0.099 & 0.472 \\
\hline 4/22/2011 16:06 & Single Vertical & 743 & 2.87 & 82.7 & 706 & 2.85 & 0.024 & 0.686 & 0.029 & 0.005 & 0.101 \\
\hline 4/22/2011 16:09 & Single Vertical & 698 & 2.84 & 82.4 & 686 & 2.83 & 0.010 & 0.276 & 0.030 & 0.001 & 0.041 \\
\hline 4/22/2011 16:14 & Point Sample & 718 & 2.86 & 82.4 & 679 & 2.83 & 0.026 & 0.745 & 0.031 & 0.007 & 0.114 \\
\hline 4/22/2011 16:17 & Point Sample & 694 & 2.84 & 82.4 & 679 & 2.83 & 0.011 & 0.323 & 0.031 & 0.001 & 0.050 \\
\hline 4/22/2011 16:40 & Pump sample & 699 & 2.84 & 81.5 & 599 & 2.78 & 0.069 & 1.674 & 0.039 & 0.060 & 0.353 \\
\hline 4/22/2011 16:44 & Single Vertical & 634 & 2.80 & 80.9 & 551 & 2.74 & 0.063 & 1.512 & 0.046 & 0.059 & 0.347 \\
\hline 4/22/2011 16:48 & Single Vertical & 599 & 2.78 & 80.9 & 551 & 2.74 & 0.038 & 1.091 & 0.046 & 0.021 & 0.207 \\
\hline 4/22/2011 16:52 & Point Sample & 595 & 2.77 & 81.5 & 603 & 2.78 & -0.004 & -0.183 & 0.039 & 0.000 & -0.020 \\
\hline 4/22/2011 16:56 & Point Sample & 563 & 2.75 & 81.6 & 611 & 2.78 & -0.034 & -1.091 & 0.038 & 0.014 & -0.164 \\
\hline 4/22/2011 17:02 & Single Vertical & 586 & 2.77 & 81.7 & 621 & 2.79 & -0.024 & -0.575 & 0.037 & 0.007 & -0.113 \\
\hline 4/22/2011 17:06 & Single Vertical & 576 & 2.76 & 81.4 & 593 & 2.77 & -0.011 & -0.372 & 0.040 & 0.001 & -0.053 \\
\hline 4/22/2011 17:55 & Pump sample & 530 & 2.72 & 80.0 & 491 & 2.69 & 0.035 & 0.939 & 0.057 & 0.024 & 0.217 \\
\hline 4/22/2011 19:45 & Pump sample & 388 & 2.59 & 80.0 & 491 & 2.69 & -0.100 & -1.896 & 0.057 & 0.191 & -0.652 \\
\hline 4/22/2011 23:05 & Pump sample & 274 & 2.44 & 78.3 & 385 & 2.58 & -0.146 & -2.295 & 0.087 & 0.654 & -1.317 \\
\hline 4/26/2011 5:50 & Pump sample & 408 & 2.61 & 77.9 & 363 & 2.56 & 0.053 & 1.383 & 0.095 & 0.096 & 0.441 \\
\hline \multicolumn{12}{|l|}{2013 ADVM Data } \\
\hline 4/18/2013 9:57 & Pump sample & 908 & 2.96 & 84.6 & 983 & 2.99 & -0.031 & -0.123 & 0.102 & 0.015 & -0.162 \\
\hline 4/18/2013 10:12 & Pump sample & 951 & 2.98 & 84.0 & 908 & 2.95 & 0.024 & 0.659 & 0.124 & 0.011 & 0.143 \\
\hline 4/18/2013 10:19 & EWI & 859 & 2.93 & 84.2 & 936 & 2.97 & -0.033 & -0.377 & 0.113 & 0.019 & -0.188 \\
\hline 4/18/2013 10:31 & EWI & 772 & 2.89 & 84.1 & 913 & 2.96 & -0.069 & -1.565 & 0.122 & 0.092 & -0.438 \\
\hline 4/18/2013 10:53 & Pump sample & 1086 & 3.04 & 84.1 & 913 & 2.96 & 0.079 & 1.007 & 0.122 & 0.122 & 0.523 \\
\hline 4/18/2013 12:28 & Pump sample & 974 & 2.99 & 84.3 & 947 & 2.97 & 0.016 & 0.377 & 0.110 & 0.004 & 0.088 \\
\hline 4/18/2013 13:25 & Pump sample & 1295 & 3.11 & 87.8 & 1491 & 3.17 & -0.057 & -1.007 & 0.376 & 0.388 & -0.900 \\
\hline 4/18/2013 13:50 & Pump sample & 1747 & 3.24 & 87.0 & 1345 & 3.12 & 0.117 & 1.565 & 0.247 & 0.734 & 1.706 \\
\hline 4/18/2013 13:56 & EWI & 1211 & 3.08 & 87.0 & 1345 & 3.12 & -0.042 & -0.659 & 0.247 & 0.093 & -0.419 \\
\hline 4/18/2013 18:49 & Pump sample & 654 & 2.82 & 81.7 & 667 & 2.82 & -0.005 & 0.123 & 0.435 & 0.004 & -0.083 \\
\hline
\end{tabular}




\begin{tabular}{|c|c|c|c|c|c|c|c|c|c|c|c|}
\hline \multicolumn{4}{|c|}{ Suspended sediment } & \multirow{2}{*}{$\begin{array}{c}\text { Acoustic } \\
\text { parameter } \\
\text { MeanSCB } \\
\text { (dB) }\end{array}$} & \multicolumn{7}{|c|}{ Rating information } \\
\hline $\begin{array}{l}\text { Date and time } \\
\text { (CST) }\end{array}$ & $\begin{array}{c}\text { Sample } \\
\text { type }\end{array}$ & $\begin{array}{r}\text { Sam } \\
\text { concent } \\
(\mathrm{mg} / \mathrm{L})\end{array}$ & $\begin{array}{l}\text { e } \\
\text { ation } \\
\log _{10} \\
\end{array}$ & & $\begin{array}{l}\text { Predicte } \\
\text { (mg/L) }\end{array}$ & $\begin{array}{l}\text { SSC } \\
\log _{10} \\
\end{array}$ & $\begin{array}{c}\text { Residual } \\
\log _{10}\end{array}$ & $\begin{array}{c}\text { Normal } \\
\text { Quantiles }\end{array}$ & Leverage & Cook's D & DFFITS \\
\hline \multicolumn{12}{|l|}{2015 ADVM Data } \\
\hline 6/7/2015 17:26 & Pump sample & 268 & 2.43 & 80.3 & --- & --- & --- & --- & --- & --- & --- \\
\hline 6/7/2015 17:56 & Pump sample & 481 & 2.68 & 79.8 & --- & --- & --- & --- & --- & --- & --- \\
\hline 6/7/2015 18:27 & Pump sample & 3320 & 3.52 & 87.8 & --- & --- & --- & --- & --- & --- & --- \\
\hline 6/7/2015 19:06 & Pump sample & 2840 & 3.45 & 86.3 & --- & --- & --- & --- & --- & --- & --- \\
\hline 6/8/2015 8:38 & Pump sample & 354 & 2.55 & 69.5 & --- & --- & --- & --- & --- & --- & --- \\
\hline 6/8/2015 9:24 & Pump sample & 125 & 2.10 & 69.7 & --- & --- & --- & --- & --- & --- & --- \\
\hline 6/8/2015 9:47 & Pump sample & 118 & 2.07 & 69.0 & --- & --- & --- & --- & --- & --- & --- \\
\hline 6/8/2015 20:16 & Pump sample & 336 & 2.53 & 74.9 & --- & --- & --- & --- & --- & --- & --- \\
\hline 6/8/2015 20:20 & Pump sample & 313 & 2.50 & 75.2 & --- & --- & --- & --- & --- & --- & --- \\
\hline 6/17/2015 13:31 & Pump sample & 171 & 2.23 & 80.3 & --- & --- & --- & --- & --- & --- & --- \\
\hline 6/17/2015 13:57 & Pump sample & 1130 & 3.05 & 83.0 & --- & --- & --- & --- & --- & --- & --- \\
\hline 6/17/2015 14:31 & Pump sample & 1150 & 3.06 & 82.0 & --- & --- & --- & --- & --- & --- & --- \\
\hline 6/17/2015 15:41 & Pump sample & 932 & 2.97 & 81.5 & --- & --- & --- & --- & --- & --- & --- \\
\hline 6/17/2015 23:51 & Pump sample & 259 & 2.41 & 72.1 & --- & --- & --- & --- & --- & --- & --- \\
\hline 7/8/2015 20:33 & Pump sample & 85 & 1.93 & 82.0 & --- & --- & --- & --- & --- & --- & --- \\
\hline 7/8/2015 20:44 & Pump sample & 117 & 2.07 & 80.5 & --- & --- & --- & --- & --- & --- & --- \\
\hline 7/8/2015 20:56 & Pump sample & 360 & 2.56 & 81.1 & --- & --- & --- & --- & --- & --- & --- \\
\hline 7/8/2015 21:07 & Pump sample & 1380 & 3.14 & 87.3 & --- & --- & --- & --- & --- & --- & --- \\
\hline 7/8/2015 21:19 & Pump sample & 1250 & 3.10 & 87.3 & --- & --- & --- & --- & --- & --- & --- \\
\hline 7/8/2015 21:31 & Pump sample & 1300 & 3.11 & 87.5 & --- & --- & --- & --- & --- & --- & --- \\
\hline 7/8/2015 21:53 & Pump sample & 1200 & 3.08 & 88.2 & --- & --- & --- & --- & --- & --- & --- \\
\hline 7/8/2015 22:28 & Pump sample & 1060 & 3.03 & 86.7 & --- & --- & --- & --- & --- & --- & --- \\
\hline 7/9/2015 5:06 & Pump sample & 255 & 2.41 & 72.7 & --- & --- & --- & --- & --- & --- & --- \\
\hline 7/9/2015 7:28 & Pump sample & 116 & 2.06 & 73.1 & --- & --- & --- & --- & --- & --- & --- \\
\hline 7/9/2015 7:35 & EWI & 103 & 2.01 & 72.9 & --- & --- & --- & --- & --- & --- & --- \\
\hline 7/9/2015 7:41 & Pump sample & 109 & 2.04 & 73.0 & --- & --- & --- & --- & --- & --- & --- \\
\hline
\end{tabular}




\begin{tabular}{|c|c|c|c|c|c|c|c|c|c|c|c|}
\hline \multicolumn{4}{|c|}{ Suspended sediment } & \multirow{3}{*}{$\begin{array}{c}\text { Acoustic } \\
\text { parameter }\end{array}$} & \multicolumn{7}{|c|}{ Rating information } \\
\hline \multirow{2}{*}{$\begin{array}{l}\text { Date and time } \\
\text { (CST) }\end{array}$} & \multirow{2}{*}{$\begin{array}{l}\text { Sample } \\
\text { type }\end{array}$} & \multicolumn{2}{|c|}{$\begin{array}{c}\text { Sample } \\
\text { concentration }\end{array}$} & & \multicolumn{2}{|c|}{ Predicted SSC } & \multirow{2}{*}{$\begin{array}{c}\text { Residual } \\
\log _{10}\end{array}$} & \multirow{2}{*}{$\begin{array}{l}\text { Normal } \\
\text { Quantiles }\end{array}$} & \multirow[b]{2}{*}{ Leverage } & \multirow[b]{2}{*}{ Cook's D } & \multirow[b]{2}{*}{ DFFITS } \\
\hline & & (mg/L) & $\log _{10}$ & & (mg/L) & $\log _{10}$ & & & & & \\
\hline \multicolumn{12}{|l|}{2011 ADCP Data } \\
\hline 4/22/2011 13:35 & Pump sample & 2260 & 3.35 & 93.0 & 2166 & 3.33 & 0.019 & 1.039 & 0.114 & 0.039 & 0.277 \\
\hline 4/22/2011 13:41 & Single Vertical & 2020 & 3.31 & 91.9 & 1892 & 3.28 & 0.029 & 1.259 & 0.084 & 0.062 & 0.354 \\
\hline 4/22/2011 13:45 & Single Vertical & 1980 & 3.30 & 91.8 & 1866 & 3.27 & 0.027 & 1.142 & 0.081 & 0.049 & 0.314 \\
\hline 4/22/2011 13:48 & Single Vertical & 1870 & 3.27 & 91.7 & 1837 & 3.26 & 0.008 & 0.502 & 0.078 & 0.005 & 0.096 \\
\hline 4/22/2011 13:54 & Pump sample & 1780 & 3.25 & 91.4 & 1772 & 3.25 & 0.003 & 0.200 & 0.072 & 0.000 & 0.030 \\
\hline 4/22/2011 13:55 & EWI & 1740 & 3.24 & 91.4 & 1769 & 3.25 & -0.006 & -0.200 & 0.071 & 0.002 & -0.068 \\
\hline 4/22/2011 14:06 & Point Sample & 1560 & 3.19 & 91.0 & 1685 & 3.23 & -0.033 & -1.797 & 0.063 & 0.056 & -0.337 \\
\hline 4/22/2011 14:09 & Point Sample & 1510 & 3.18 & 90.7 & 1615 & 3.21 & -0.028 & -1.259 & 0.057 & 0.037 & -0.274 \\
\hline 4/22/2011 14:12 & Point Sample & 1500 & 3.18 & 90.2 & 1531 & 3.18 & -0.008 & -0.439 & 0.049 & 0.003 & -0.070 \\
\hline 4/22/2011 14:13 & Point Sample & 1430 & 3.16 & 90.3 & 1543 & 3.19 & -0.032 & -1.565 & 0.050 & 0.042 & -0.291 \\
\hline 4/22/2011 14:18 & Point Sample & 1390 & 3.14 & 89.4 & 1381 & 3.14 & 0.004 & 0.258 & 0.037 & 0.000 & 0.027 \\
\hline 4/22/2011 14:22 & Point Sample & 1390 & 3.14 & 89.4 & 1384 & 3.14 & 0.003 & 0.142 & 0.038 & 0.000 & 0.019 \\
\hline 4/22/2011 14:25 & Point Sample & 1320 & 3.12 & 88.9 & 1294 & 3.11 & 0.009 & 0.568 & 0.032 & 0.002 & 0.064 \\
\hline 4/22/2011 14:33 & Single Vertical & 1270 & 3.10 & 89.2 & 1347 & 3.13 & -0.025 & -1.039 & 0.035 & 0.017 & -0.183 \\
\hline 4/22/2011 14:35 & Single Vertical & 1230 & 3.09 & 87.9 & 1150 & 3.06 & 0.030 & 1.395 & 0.025 & 0.017 & 0.185 \\
\hline 4/22/2011 14:47 & Point Sample & 1100 & 3.04 & 87.3 & 1066 & 3.03 & 0.014 & 0.861 & 0.023 & 0.004 & 0.084 \\
\hline 4/22/2011 14:49 & Point Sample & 1140 & 3.06 & 86.8 & 1001 & 3.00 & 0.057 & 1.797 & 0.023 & 0.057 & 0.354 \\
\hline 4/22/2011 14:56 & Single Vertical & 1080 & 3.03 & 87.4 & 1086 & 3.04 & -0.002 & 0.085 & 0.023 & 0.000 & -0.009 \\
\hline 4/22/2011 14:59 & Single Vertical & 1070 & 3.03 & 87.9 & 1149 & 3.06 & -0.030 & -1.395 & 0.025 & 0.017 & -0.187 \\
\hline 4/22/2011 15:01 & Point Sample & 1030 & 3.01 & 87.2 & 1049 & 3.02 & -0.007 & -0.317 & 0.023 & 0.001 & -0.043 \\
\hline 4/22/2011 15:04 & Point Sample & 1010 & 3.00 & 87.3 & 1064 & 3.03 & -0.022 & -0.947 & 0.023 & 0.008 & -0.129 \\
\hline 4/22/2011 15:07 & Single Vertical & 1020 & 3.01 & 86.9 & 1011 & 3.00 & 0.005 & 0.377 & 0.023 & 0.000 & 0.028 \\
\hline $4 / 22 / 2011$ 15:10 & Single Vertical & 970 & 2.99 & 86.3 & 942 & 2.97 & 0.013 & 0.782 & 0.024 & 0.003 & 0.080 \\
\hline $4 / 22 / 2011$ 15:13 & Point Sample & 979 & 2.99 & 86.9 & 1020 & 3.01 & -0.017 & -0.861 & 0.023 & 0.005 & -0.099 \\
\hline 4/22/2011 15:20 & Point Sample & 995 & 3.00 & 86.8 & 1002 & 3.00 & -0.002 & 0.028 & 0.023 & 0.000 & -0.013 \\
\hline 4/22/2011 15:23 & Single Vertical & 889 & 2.95 & 86.3 & 945 & 2.97 & -0.026 & -1.142 & 0.024 & 0.012 & -0.156 \\
\hline 4/22/2011 15:26 & Single Vertical & 908 & 2.96 & 86.1 & 923 & 2.96 & -0.006 & -0.142 & 0.025 & 0.001 & -0.037 \\
\hline
\end{tabular}




\begin{tabular}{|c|c|c|c|c|c|c|c|c|c|c|c|}
\hline \multicolumn{4}{|c|}{ Suspended sediment } & \multirow{2}{*}{$\begin{array}{c}\text { Acoustic } \\
\text { parameter } \\
\text { MeanSCB } \\
\text { (dB) }\end{array}$} & \multicolumn{7}{|c|}{ Rating information } \\
\hline $\begin{array}{l}\text { Date and time } \\
\text { (CST) }\end{array}$ & $\begin{array}{c}\text { Sample } \\
\text { type }\end{array}$ & $\begin{array}{l}\text { Samp } \\
\text { concent } \\
\text { (mg/L) }\end{array}$ & $\begin{array}{l}\text { e } \\
\text { ation } \\
\log _{10}\end{array}$ & & $\begin{array}{l}\text { Predicted } \\
\text { (mg/L) }\end{array}$ & $\begin{array}{l}\text { SSC } \\
\log _{10}\end{array}$ & $\begin{array}{c}\text { Residual } \\
\log _{10}\end{array}$ & $\begin{array}{c}\text { Normal } \\
\text { Quantiles }\end{array}$ & Leverage & Cook's D & DFFITS \\
\hline 4/22/2011 15:42 & Point Sample & 822 & 2.91 & 85.3 & 836 & 2.92 & -0.007 & -0.258 & 0.029 & 0.001 & -0.044 \\
\hline $4 / 22 / 2011$ 15:45 & Point Sample & 812 & 2.91 & 85.2 & 821 & 2.91 & -0.004 & -0.085 & 0.031 & 0.000 & -0.027 \\
\hline 4/22/2011 15:49 & Single Vertical & 744 & 2.87 & 84.6 & 765 & 2.88 & -0.011 & -0.568 & 0.037 & 0.004 & -0.083 \\
\hline 4/22/2011 15:56 & Single Vertical & 791 & 2.90 & 84.6 & 765 & 2.88 & 0.015 & 0.947 & 0.037 & 0.007 & 0.115 \\
\hline 4/22/2011 15:59 & Point Sample & 756 & 2.88 & 84.3 & 736 & 2.87 & 0.012 & 0.707 & 0.041 & 0.005 & 0.098 \\
\hline 4/22/2011 16:02 & Point Sample & 734 & 2.87 & 84.1 & 719 & 2.86 & 0.010 & 0.636 & 0.043 & 0.003 & 0.079 \\
\hline 4/22/2011 16:05 & Pump sample & 896 & 2.95 & 84.2 & 727 & 2.86 & 0.092 & 2.209 & 0.042 & 0.278 & 0.881 \\
\hline 4/22/2011 16:06 & Single Vertical & 743 & 2.87 & 84.3 & 737 & 2.87 & 0.004 & 0.317 & 0.040 & 0.001 & 0.033 \\
\hline 4/22/2011 16:09 & Single Vertical & 698 & 2.84 & 84.1 & 720 & 2.86 & -0.013 & -0.636 & 0.043 & 0.006 & -0.106 \\
\hline 4/22/2011 16:14 & Point Sample & 718 & 2.86 & 84.0 & 711 & 2.85 & 0.005 & 0.439 & 0.045 & 0.001 & 0.043 \\
\hline $4 / 22 / 2011$ 16:40 & Pump sample & 699 & 2.84 & 83.2 & 642 & 2.81 & 0.038 & 1.565 & 0.058 & 0.069 & 0.376 \\
\hline 4/22/2011 16:44 & Single Vertical & 634 & 2.80 & 83.2 & 640 & 2.81 & -0.003 & -0.028 & 0.059 & 0.001 & -0.032 \\
\hline 4/22/2011 16:48 & Single Vertical & 599 & 2.78 & 82.9 & 621 & 2.79 & -0.015 & -0.782 & 0.064 & 0.012 & -0.152 \\
\hline 4/22/2011 16:52 & Point Sample & 595 & 2.77 & 83.9 & 701 & 2.85 & -0.070 & -2.209 & 0.046 & 0.183 & -0.660 \\
\hline $4 / 22 / 2011$ 16:56 & Point Sample & 563 & 2.75 & 82.4 & 581 & 2.76 & -0.013 & -0.707 & 0.075 & 0.011 & -0.146 \\
\hline 4/22/2011 17:02 & Single Vertical & 586 & 2.77 & 82.6 & 598 & 2.78 & -0.008 & -0.502 & 0.070 & 0.004 & -0.089 \\
\hline 4/22/2011 17:06 & Single Vertical & 576 & 2.76 & 82.5 & 587 & 2.77 & -0.008 & -0.377 & 0.073 & 0.004 & -0.086 \\
\hline
\end{tabular}




\section{Appendix 5. Rating Equation Forms}

[MeanSCB, average sediment corrected backscatter; SAC, sediment attenuation coefficient; mg/L, milligrams per liter; SSC, suspended-sediment concentration; $\mathrm{dB}$, decibels; $\mathrm{dB} / \mathrm{m}$, decibels per meter; log10, base-10 logarithmic transform; $\mathrm{R}^{2}$, coefficient of determination; SE, standard error; tStat, t statistic; Cook’s D, Cook’s distance; DFFITS, difference in fit statistic]

\begin{tabular}{|c|c|c|c|}
\hline \multicolumn{4}{|c|}{ Rating equation form for Configuration 2} \\
\hline \multicolumn{4}{|c|}{$\log _{10} \mathrm{SSC}=-2.14+0.0604 \mathrm{MeanSCB}$} \\
\hline \multicolumn{4}{|c|}{ Explanatory and response variable summary statistics } \\
\hline & MeanSCB (dB) & $\mathrm{SSC}(\mathrm{mg} / \mathrm{L})$ & $\log _{10}(\mathrm{SSC})$ \\
\hline Minimum & 78 & 274 & 2.438 \\
\hline 1st quartile & 82 & 722 & 2.859 \\
\hline Median & 85 & 1010 & 3.004 \\
\hline Mean & 85 & 1182 & 3.015 \\
\hline 3rd quartile & 89 & 1483 & 3.171 \\
\hline Maximum & 93 & 3000 & 3.477 \\
\hline
\end{tabular}

\section{Rating calibration}

Number of observations

Error degrees of freedom

Root mean square error (standard error)

$\mathrm{R}^{2}$

Adjusted $\mathrm{R}^{2}$

F-statistic versus constant model

p-value

\section{Estimated coefficients}

(Intercept)

MeanSCB

Non-parametric smearing bias correction

factor

Probability plot correlation coefficient

Variance-covariance matrix

(Intercept)

MeanSCB

Test criteria

High leverage
0.041187

0.968

0.967

1600

3.06E-41

\section{Estimate}

$-2.1428$

0.0604

1.004

0.9694

\section{SE}

0.1292

0.0015

tStat

$-16.5800$

pValue

Lower $90 \%$

$-2.3592$

0.0578
Upper $90 \%$

$-1.9265$

0.0629

\subsection{9}




\begin{tabular}{|lr}
\hline Extreme outlier (standardized residual) & 3 (absolute value) \\
High influence (Cook's D) & 2.183 \\
High influence (DFFITS) & 0.38139 \\
\hline
\end{tabular}

\section{Rating equation form for Configuration 3}

$\log _{10}$ SSC $=-1.84+0.0571$ MeanSCB

Explanatory and response variable summary statistics

Minimum

$\begin{array}{rrr}\text { MeanSCB }(\mathrm{dB}) & \mathrm{SSC}(\mathrm{mg} / \mathrm{L}) & \log _{10}(\mathrm{SSC}) \\ 82 & 654 & 2.816 \\ 84 & 859 & 2.934 \\ 84 & 963 & 2.983 \\ 85 & 1046 & 3.004 \\ 87 & 1211 & 3.083 \\ 88 & 1747 & 3.242\end{array}$

Rating calibration

Number of observations $\quad 10$

Error degrees of freedom 8

Root mean square error (standard error) 0.06398

$\mathrm{R}^{2}$

0.753

Adjusted $\mathrm{R}^{2}$

0.722

F-statistic versus constant model

24.4

p-value

0.00113

\section{Estimated coefficients}

(Intercept)

MeanSCB

Non-parametric smearing bias correction

factor

Probability plot correlation coefficient

Variance-covariance matrix

(Intercept)

MeanSCB

Test criteria

High leverage

Extreme outlier (standardized residual)

High influence (Cook's D)

High influence (DFFITS)

\section{Estimate}

$-1.8428$

0.0571

1.009

0.9590

(Intercept)

0.96189

$-0.011328$

0.6

3 (absolute value)

2.606

0.89443
MeanSCB

$-0.011328$

0.00013346 


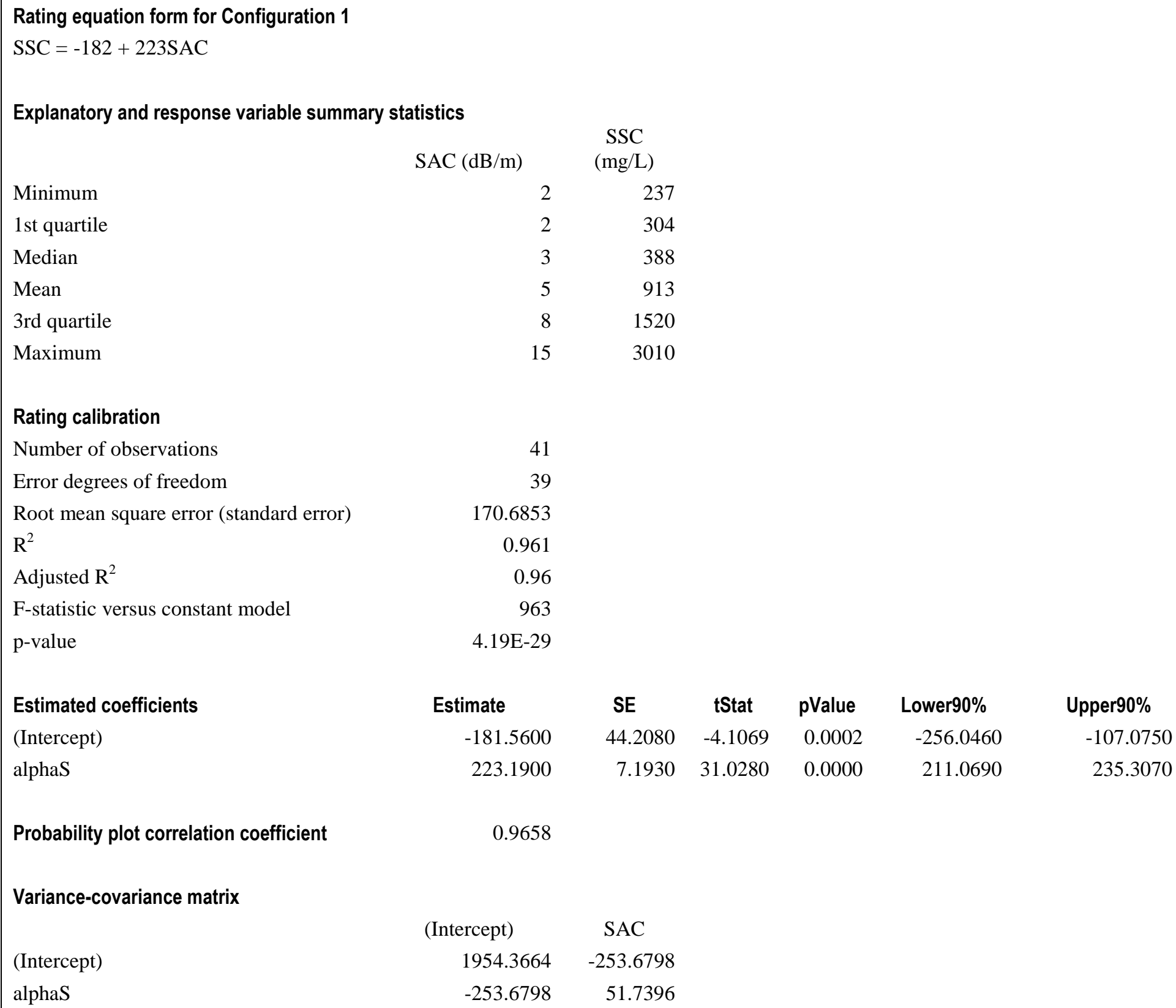

Probability plot correlation coefficient

0.9658

Variance-covariance matrix

(Intercept)

\section{(Intercept)}

1954.3664

$-253.6798$

0.14634

3 (absolute value)

2.216 0.44173

\section{Rating equation form for Configuration 4}

SSC $=-75.9+151$ SAC 


\begin{tabular}{|c|c|c|c|c|c|c|}
\hline \multicolumn{7}{|c|}{ Explanatory and response variable summary statistics } \\
\hline & $\mathrm{SAC}(\mathrm{dB} / \mathrm{m})$ & $\begin{array}{l}\text { SSC } \\
(\mathrm{mg} / \mathrm{L})\end{array}$ & & & & \\
\hline Minimum & 1.269 & 85.0 & & & & \\
\hline 1st quartile & 2.346 & 125.0 & & & & \\
\hline Median & 3.536 & 345.0 & & & & \\
\hline Mean & 5.384 & 735.8 & & & & \\
\hline 3rd quartile & 6.229 & 1150.0 & & & & \\
\hline Maximum & 23.952 & 3320.0 & & & & \\
\hline \multicolumn{7}{|l|}{ Rating calibration } \\
\hline Number of observations & 26 & & & & & \\
\hline Error degrees of freedom & 24 & & & & & \\
\hline Root mean square error (standard error) & 282.8318 & & & & & \\
\hline $\mathrm{R}^{2}$ & 0.888 & & & & & \\
\hline Adjusted $\mathrm{R}^{2}$ & 0.884 & & & & & \\
\hline F-statistic versus constant model & 191 & & & & & \\
\hline p-value & $6.3 \mathrm{E}-13$ & & & & & \\
\hline Estimated coefficients & Estimate & SE & tStat & pValue & Lower90\% & Upper $90 \%$ \\
\hline (Intercept) & -75.9360 & 80.7660 & -0.9402 & 3.56E-01 & -214.1180 & 62.2454 \\
\hline alphaS & 150.7800 & 10.9040 & 13.8280 & $6.30 \mathrm{E}-13$ & 132.1270 & 169.4390 \\
\hline Probability plot correlation coefficient & 0.9706 & & & & & \\
\hline \multicolumn{7}{|l|}{ Variance-covariance matrix } \\
\hline & (Intercept) & SAC & & & & \\
\hline (Intercept) & 6523.2097 & -640.1667 & & & & \\
\hline alphaS & -640.1667 & 118.9063 & & & & \\
\hline \multicolumn{7}{|l|}{ Test criteria } \\
\hline High leverage & 0.23077 & & & & & \\
\hline Extreme outlier (standardized residual) & 3 (absolute value) & & & & & \\
\hline High influence (Cook's D) & 2.291 & & & & & \\
\hline High influence (DFFITS) & 0.5547 & & & & & \\
\hline
\end{tabular}




\section{Appendix 6. Turbidity}

Linear regression models with suspended-sediment concentration (SSC) as the response variable were developed for the YSI 6920 instrument and the SOLITAX instrument for 2013 and 2015 (fig. 6-1). These turbidity models were created in tandem with the acoustic models to demonstrate that the observed scatter in configuration 3000-4 of the ADVM was also seen in the turbidity models. Because this appears in 3 instruments, it is unlikely that the scatter seen in the acoustic model was caused by a different configuration.

In 2013, the model for the YSI 6920 produced a coefficient of determination of 0.35, and the model for the SOLITAX produced a coefficient of determination of 0.73. In 2015, the model for the YSI 6920 produced a coefficient of determination of 0.88 , and the model for the SOLITAX produced a coefficient of determination of 0.82 . Turbidity values range only from 750 to 1300 formazin nephelometric units and 745 to 1480 formazin backscatter ratio units (table 6-1) for the concurrent samples in 2013, and the coefficients of determination are not as high as the 2015 regression results, but the overall trend of the data in 2013 matches well with the 2015 data. It is noted that the 2013 SOLITAX data are shifted slightly from the 2015 SOLITAX data because of an adjustment to the instrument. The regressions in figure 6-1 can then be used to predict SSC and plot with observed SSC around a line of perfect agreement (fig. 6-2). The SSC values used in the linear models ranged from 654 to $1,747 \mathrm{mg} / \mathrm{L}$ in 2013 and from 103 to 3,320 $\mathrm{mg} / \mathrm{L}$ in 2015. The data used to build the models are presented in table 6-1. 

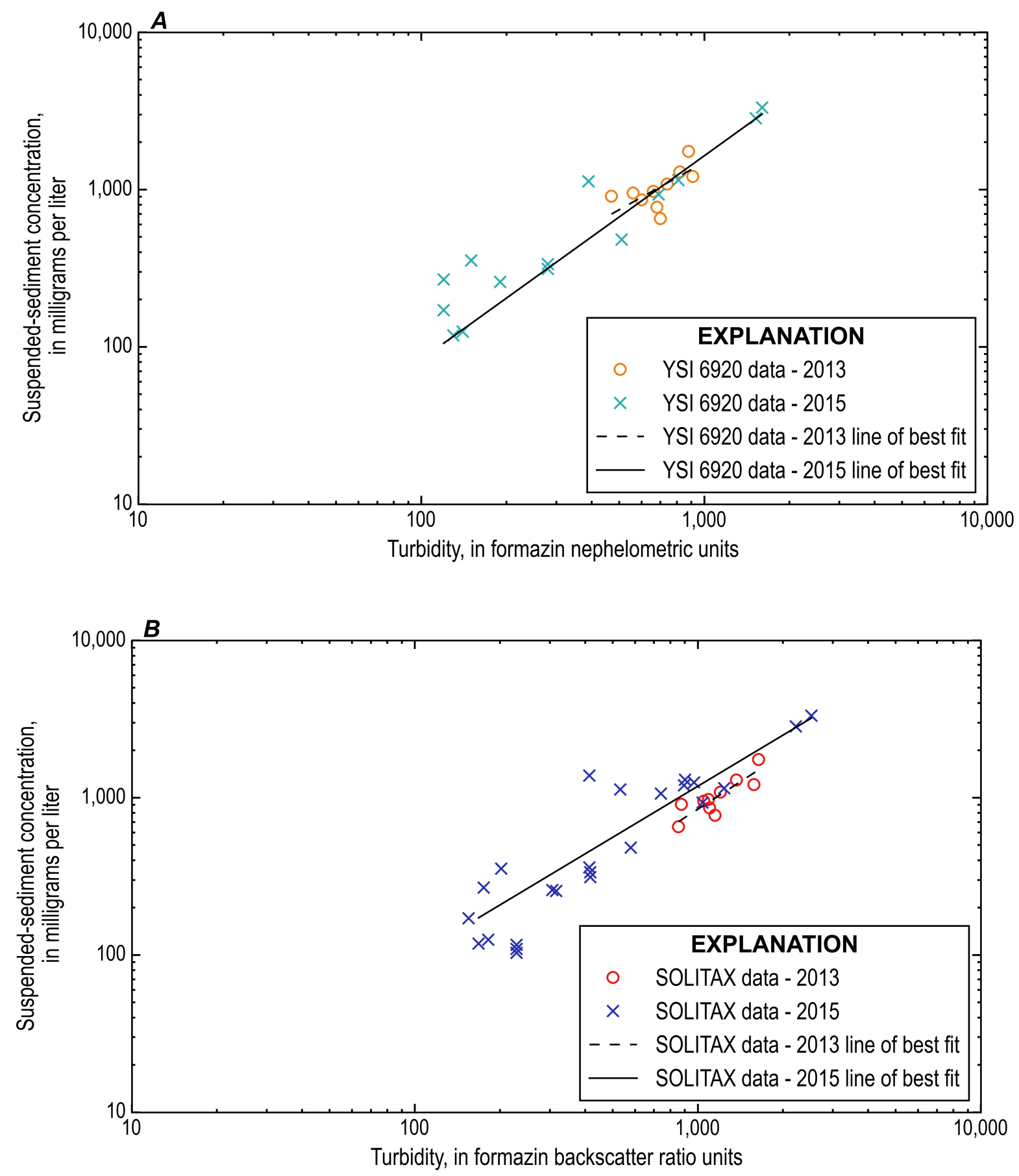

Figure 6-1. Suspended-sediment concentration and turbidity linear regression models using turbidity data for $(A)$ the YSI 6920 instrument, and (B) the SOLITAX instrument. 


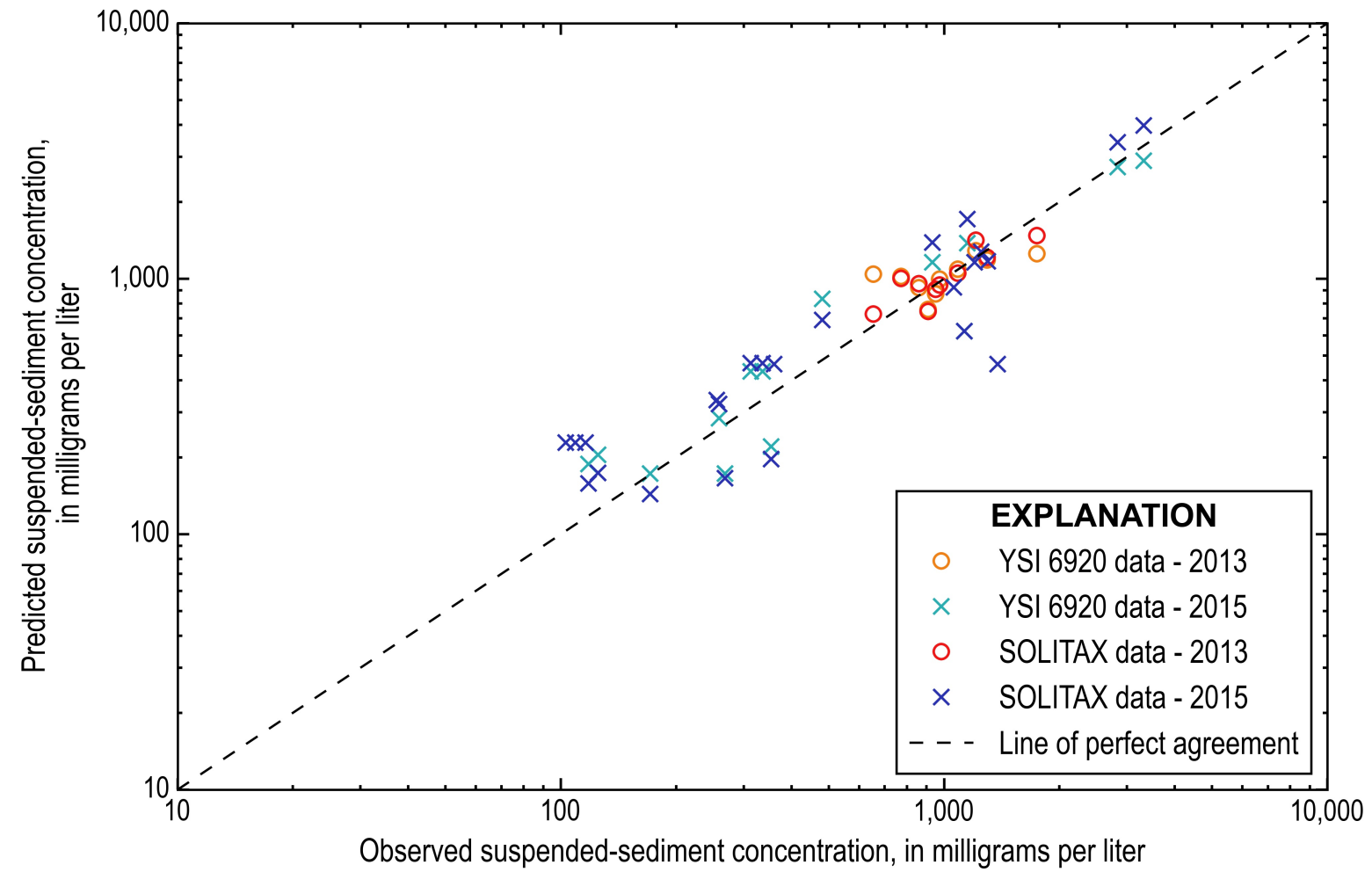

Figure 6-2. Predicted and observed suspended-sediment concentration using turbidity linear regression models presented in fig. 6-1. 
Table 6-1. Data from the YSI 6920 and the SOLITAX that were used in the turbidity analysis.

[SSC, suspended-sediment concentration; ADVM, acoustic Doppler velocity meter; mg/L, milligrams per liter; FNU, formazin nephelometric unit; FBRU, formazin backscatter ratio unit; CST, Central (U.S.) standard time; ---, no data]

\begin{tabular}{|c|c|c|c|c|c|}
\hline \multicolumn{4}{|c|}{ Suspended Sediment } & \multirow{2}{*}{\multicolumn{2}{|c|}{$\begin{array}{l}\text { Surrogate } \\
\text { Turbidity }\end{array}$}} \\
\hline \multirow{2}{*}{$\begin{array}{c}\text { Date and Time } \\
\text { (CST) }\end{array}$} & \multirow{2}{*}{$\begin{array}{c}\text { Physical Sample } \\
\text { SSC } \\
(\mathrm{mg} / \mathrm{L}) \\
\end{array}$} & \multicolumn{2}{|c|}{ Predicted SSC } & & \\
\hline & & (FNU) & (FBRU) & $(\mathrm{FNU})$ & (FBRU) \\
\hline \multicolumn{6}{|c|}{2013 Data Concurrent with ADVM } \\
\hline 04/18/2013 09:57 & 908 & 758.905 & 745.201 & 470 & 875 \\
\hline 04/18/2013 10:12 & 951 & 873.146 & 908.739 & 560 & 1050 \\
\hline 04/18/2013 10:19 & 859 & 922.716 & 955.927 & 600 & 1100 \\
\hline 04/18/2013 10:31 & 772 & 1019.94 & 1003.3 & 680 & 1150 \\
\hline 04/18/2013 10:53 & 1086 & 1091.35 & 1050.86 & 740 & 1200 \\
\hline 04/18/2013 12:28 & 974 & 995.857 & 946.474 & 660 & 1090 \\
\hline 04/18/2013 13:25 & 1295 & 1184.8 & 1213.84 & 820 & 1370 \\
\hline 04/18/2013 13:50 & 1747 & 1253.7 & 1476.3 & 880 & 1640 \\
\hline 04/18/2013 13:56 & 1211 & 1287.79 & 1417.62 & 910 & 1580 \\
\hline 04/18/2013 18:49 & 654 & 1044 & 726.684 & 700 & 855 \\
\hline \multicolumn{6}{|c|}{2015 Data Concurrent with ADVM } \\
\hline 06/07/2015 17:26 & 268 & 172.83 & 165.912 & 120 & 175 \\
\hline 06/07/2015 17:56 & 481 & 834.172 & 690.32 & 510 & 579 \\
\hline 06/07/2015 18:27 & 3320 & 2893.75 & 3982.1 & 1600 & 2520 \\
\hline 06/07/2015 19:06 & 2840 & 2736.7 & 3423.9 & 1520 & 2220 \\
\hline 06/08/2015 08:38 & 354 & 220.318 & 196.847 & 150 & 202 \\
\hline 06/08/2015 09:24 & 125 & 204.387 & 173.85 & 140 & 182 \\
\hline 06/08/2015 09:47 & 118 & 188.555 & 158.035 & 130 & 168 \\
\hline 06/08/2015 20:16 & 336 & 434.459 & 466.881 & 280 & 417 \\
\hline 06/08/2015 20:20 & 313 & 434.459 & 466.881 & 280 & 417 \\
\hline 06/17/2015 13:31 & 171 & 172.83 & 143.575 & 120 & 155 \\
\hline 06/17/2015 13:57 & 1130 & 623.027 & 624.082 & 390 & 532 \\
\hline 06/17/2015 14:31 & 1150 & 1379.86 & 1710.58 & 810 & 1240 \\
\hline 06/17/2015 15:41 & 932 & 1158.98 & 1387.15 & 690 & 1040 \\
\hline 06/17/2015 23:51 & 259 & 284.93 & 322.883 & 190 & 306 \\
\hline 07/08/2015 20:56 & 360 & --- & 462.881 & --- & 414 \\
\hline 07/08/2015 21:07 & 1380 & --- & 462.881 & --- & 414 \\
\hline 07/08/2015 21:19 & 1250 & --- & 1276.63 & --- & 970 \\
\hline 07/08/2015 21:31 & 1300 & --- & 1170.73 & --- & 902 \\
\hline 07/08/2015 21:53 & 1200 & --- & 1159.91 & --- & 895 \\
\hline 07/08/2015 22:28 & 1060 & --- & 926.215 & --- & 741 \\
\hline 07/09/2015 05:06 & 255 & --- & 335.495 & --- & 316 \\
\hline 07/09/2015 07:28 & 116 & --- & 228.585 & --- & 229 \\
\hline 07/09/2015 07:35 & 103 & --- & 228.585 & --- & 229 \\
\hline 07/09/2015 07:41 & 109 & --- & 228.585 & --- & 229 \\
\hline
\end{tabular}


http://dx.doi.org/10.3133/ofr20161117 ISSN 2331-1258 (online) 